\title{
Halophiles and Their Biomolecules: Recent Advances and Future Applications in Biomedicine
}

\author{
Paulina Corral 1,2 (D), Mohammad A. Amoozegar ${ }^{3}$ (D) and Antonio Ventosa $2, *(\mathbb{D})$ \\ 1 Department of Biology, University of Naples Federico II, 80126 Naples, Italy; pcv@us.es \\ 2 Department of Microbiology and Parasitology, Faculty of Pharmacy, University of Sevilla, \\ 41012 Sevilla, Spain \\ 3 Department of Microbiology, School of Biology, College of Science, University of Tehran, \\ Tehran 14155-6955, Iran; amoozegar@ut.ac.ir \\ * Correspondence: ventosa@us.es; Tel.: +34-954556765
}

Received: 30 November 2019; Accepted: 28 December 2019; Published: 30 December 2019

check for updates

\begin{abstract}
The organisms thriving under extreme conditions better than any other organism living on Earth, fascinate by their hostile growing parameters, physiological features, and their production of valuable bioactive metabolites. This is the case of microorganisms (bacteria, archaea, and fungi) that grow optimally at high salinities and are able to produce biomolecules of pharmaceutical interest for therapeutic applications. As along as the microbiota is being approached by massive sequencing, novel insights are revealing the environmental conditions on which the compounds are produced in the microbial community without more stress than sharing the same substratum with their peers, the salt. In this review are reported the molecules described and produced by halophilic microorganisms with a spectrum of action in vitro: antimicrobial and anticancer. The action mechanisms of these molecules, the urgent need to introduce alternative lead compounds and the current aspects on the exploitation and its limitations are discussed.
\end{abstract}

Keywords: halophilic bacteria; archaea and fungi; biomolecules; biomedicine; antimicrobial compounds; anticancer compounds

\section{Halophilic Microorganisms}

Halophiles are organisms represented by archaea, bacteria, and eukarya for which the main characteristic is their salinity requirement, halophilic "salt-loving". Halophilic microorganisms constitute the natural microbial communities of hypersaline ecosystems, which are widely distributed around the world [1]. They require sodium ions for their growth and metabolism. Thus, based on the $\mathrm{NaCl}$ optimal requirement for growth the halophiles are classified in three different categories: slight (1-3\%); moderate (3-15\%); and extreme (15-30\%) [2,3]. In contrast to halotolerant organisms, obligate halophiles require $\mathrm{NaCl}$ concentrations higher than $3 \% \mathrm{NaCl}$ or above of seawater, with about $3.5 \% \mathrm{NaCl}$ [4]. The tolerance parameters and salt requirements are dependent on temperature, $\mathrm{pH}$, and growth medium. In this way, the halophiles are adapted and limited by specific environmental factors. Those microorganisms able to survive and optimally thrive under a wide spectrum of extreme environmental factors are designed polyextremophiles [5,6]. In fact, a halophilic microorganism can also be alkaliphile, designated as haloalkaliphile, growing optimally or very well at $\mathrm{pH}$ values above 9.0, but cannot grow at the near neutral $\mathrm{pH}$ value of 6.5 [7].

The general features of halophilic microorganisms are the low nutritional requirements and resistance to high concentrations of salt with the capacity to balance the osmotic pressure of the environment [8]. Their mechanisms of haloadaptation are based on the intracellular storage of $\mathrm{KCl}$ over $37 \%$ (5 M) (salt-in strategy) or the accumulation of compatible solutes (salt-out strategy) to keep the balance of sodium into the 
cytoplasm and counteract the osmotic pressure of the external environment given by the high salinity [9]. They are physiologically diverse; mostly aerobic and as well anaerobic, heterotrophic, phototrophic, and chemoautotrophic $[10,11]$. Ecologically, the halophilic microorganisms inhabit different ecosystems characterized by a salinity higher than seawater, i.e., $3.5 \% \mathrm{NaCl}$, these niches go from hypersaline soils, springs, salt lakes, sabkhas, and other naturally-occurring coastal saline habitats, marshes, marine abyssal sediments to endophytes [12]. Other known habitats are the result of human intervention like salted foods, brines, oil fields, saltern ponds and tanneries [13]. The high salinity reduces the number of organisms where just halophilic or halotolerant ones can survive in such hypersaline ecosystem, with archaea typically dominating the higher salinity environments. The predominant natural habitats better studied are the hypersaline lakes of oceanic (thalassohaline) or non-oceanic (athalassohaline) origin and solar salterns [14-16]. The better known hypersaline environments are the Great Salt Lake and the Dead Sea, with $\mathrm{pH}$ values around 7, and soda lakes with highly alkaline values of $\mathrm{pH} 9-11$, among them are the Lake Magadi in Kenya, the Wadi Natrun lakes in Egypt, Mono Lake, Big Soda Lake, Soap Lake in Western USA, and Kulunda Steppe soda lakes in Russia [17]. Many new species of bacteria and archaea have been reported from various hypersaline regions located in different countries, mainly China, Spain, USA, Austria, Australia, Egypt, Korea, Japan, Iran, Thailand, Indonesia, Russia, Argentina, Kenya, Mexico, France, Poland, Philippines, Taiwan, Romania, and India $[10,18,19]$. The vast majority of halophilic bacteria and archaea produce carotenoid pigments, present in high amount in their membranes. The dense community of halophiles and the algae Dunaliella, also producer of carotenoids, are the responsible of the typical pink, red, and purple coloration of the hypersaline environments [20].

\section{Biotechnological Importance/Interest of Haloarchaea and Halophilic Bacteria}

The exploitation of extremophiles is having special importance in the development of new molecules with potential applications in biomedicine. Current efforts are focused primarily to cover the urgent health needs, especially those that represent the main global threats, cancer and antibiotic resistance. The great metabolic versatility of halophilic microorganisms, their low nutritional requirements and their genetic machineries of adaptation to harsh conditions, like nutrient starvation, desiccation, high sun radiation, and high ionic strength, make them promising candidates and a hope for drug discovery [21]. Continuous advances in "omics" and bioinformatic tools are revealing uncountable encoding genes for the production of several active compound in response to the extreme conditions [22,23]. The concomitant application of cutting-edge technologies is helping to deciphering the molecular, physiological, and metabolic mechanisms for the production of new bioactive compounds [24].

Halophilic microorganisms are recognized producers of carotenoid pigments, retinal proteins, hydrolytic enzymes, and compatible solutes as macromolecules stabilizers, biopolymers, and biofertilizers [19,25]. Halophilic bacteria and extremely halophilic aerobic archaea, also known as haloarchaea, play a significant role in the industry with a large number of applications like fermented food products, cosmetics, preservatives, manufacturing of bioplastics, photoelectric devices, artificial retinas, holograms, biosensors, etc. [26-31].

In this review, we focus on the biomolecules described as antimicrobial or anticancer compounds produced by halophilic bacteria, archaea, or fungi and discuss current and future perspectives in this field.

\section{Antimicrobial Compounds}

The current situation of antibiotic resistance propagation poses a global threat to public health. Over the past decades, antibiotics have saved millions of lives, but their misuse has led to the emergence of multi-drug resistant bacteria (MDR), reducing or nullifying their effectiveness. Recently, the continuous increase in antibiotic resistance is reaching critical levels, which implies an increase in morbidity in the healthy population and an imminent risk for hospitalized patients [32,33]. In fact, the main cause of death of inpatients are attributable to complications due to MDR infections [34]. Preventing the return to the pre-antibiotic era is one of the main challenges for science. The urgent need to introduce new effective antimicrobial therapies is leading to the exploitation of all possible 
natural and sustainable resources, including extreme environments as a promising resource for new antibiotic discovery.

The first antimicrobial compounds from halophilic microorganisms were reported in 1982 by Rodriguez-Valera et al. Halocin was the term coined for substances secreted by several members of the genus Halobacterium capable of causing death and lysis of the surrounding microbiota. Halocins are the proteins and antimicrobial peptides (AMPs) produced by haloarchaea $[35,36]$. Despite the ecological and environmental role of several halocins, their action against human pathogens has been less studied.

In the fight against time, the clinical significance of halophilic microorganisms is minorly reported and the antimicrobial action against the most important risk group of human pathogens ESKAPE: Enterococcus faecium, Staphylococcus aureus, Klebsiella pneumoniae, Acinetobacter baumannii, and Pseudomonas aeruginosa, still remains as a potential.

According to the data inferred, the antagonistic action identified and the production of bioactive compounds by halophilic microorganisms are derived from bacteria, archaea, and fungi. In the chronology of AMPS discovery, several authors have gone beyond the primary screenings deciphering the chemical structure of the molecules in bacteria (Table 1), while the vast majority of inhibitory studies are solely limited to the activity (Table 2).

\subsection{Bacteria}

Members of the phylum Actinobacteria are mainly responsible for the inhibitory activity against human pathogens with clinical significance. As in non-extreme environments, in saline and hypersaline environments heterotrophic bacteria are also present in soils, being Actinobacteria frequently isolated from solar salterns, mangroves, and seafloor sediments $[37,38]$. The most frequent producers of metabolites reported come from species of the genus Nocardiopsis and Streptomyces, hence constituting the main producers of bioactive compounds. In fact, members of the genus Streptomyces are widely recognized as fruitful producers of natural compounds [39]. The chemical elucidation of molecules known from halophilic members of Nocardiopsis are: (i) pyrrolo (1,2-A (pyrazine-1,4-dione, hexahydro-3-[2-methylpropyl]-) and Actinomycin C2, two compounds produced by the haloalkaliphilic strain Nocardiopsis sp. AJ1, isolated from saline soil of Kovalam solar salterns in India [40]; (ii) Angucyclines and Angucyclinones are produced by Nocardiopsis sp. HR-4, isolated from a salt lake soil in Algerian Sahara, the new natural compound was established as 7-deoxy-8-O-methyltetrangomycin, which is also effective against Methicillin-Resistant Staphylococcus aureus (MRSA) ATCC 43300 [41]; (iii) Borrelidin C and D are produced by Nocardiopsis sp. HYJ128, isolated from topsoil saltern in Jeungdo, Jeollanamdo, Republic of Korea, exhibited antimicrobial action against Salmonella enterica ATCC 14028 [42]; (iv) Quinoline alkaloid (4-oxo-1,4-dihydroquinoline-3-carboxamide) was identified as a new natural product from Nocardiopsis terrae YIM 90022 isolated from saline soils in China. The antibacterial activity of the quinolone was reported in S. aureus, B. subtilis and E. coli; the quinolone has also antifungal activity against the pathogenic fungi, as it was observed against Pyricularia oryzae. Another five known compounds were also produced by N. terrae YIM 90022 [43]; (v) new p-terphenyls: p-terphenyl 1 and a novel p-terphenyl derivative bearing a benzothiazole moiety are produced by halophilic actinomycete Nocardiopsis gilva YIM 90087, isolated from a hypersaline soil Xinjiang, China. Furthermore, of the antimicrobial activity against clinical strains, these compounds exhibit antifungal activity against species of Fusarium, Trichophyton, Aspergillus, Candida, and Pyricularia. Known molecules like p-terphenyl 2, novobiocin, cyclodipeptides, and aromatic acids are also produced by N. gilva YIM 90087, which is considered as a new source for novobiocin [44].

Regarding the metabolites produced by members of the genus Streptomyces, only a low number of strains has been isolated from hypersaline environments; however, members of this genus are frequently isolated from marine deep or coastal sediments where the salinity is higher than that of seawater. Among the molecules identified are: (i) 1-hydroxy-1-norresistomycin, this quinone-related antibiotic was extracted from Streptomyces chibaensis AUBN1/7, isolated from marine sediment samples of the Bay of Bengal, India. This compound exhibited antibacterial activities against Gram-positive and Gram-negative bacteria, besides of a potent in vitro cytotoxic activity against cell lines HMO2 (gastric 
adenocarcinoma) and HePG2 (hepatic carcinoma) [45]; (ii) Himalomycin A and Himalomycin B, two new anthracycline antibiotics produced by Streptomyces sp. strain B692, isolated from sandy sediment of a coastal site of Mauritius (Indian Ocean). In addition, known metabolites like rabelomycin, fridamycin D, $\mathrm{N}$ benzylacetamide, and N-(2'-phenylethyl) acetamide were also produced by Streptomyces sp. strain B692 [46]; (iii) 7-demethoxy rapamycin was produced by a moderately halophilic strain Streptomyces hygroscopicus BDUS 49, isolated from seashore of Bigeum Island, South West coast of South Korea; the molecule displayed a broad spectrum antimicrobial activity against Gram-positive and Gram-negative bacteria. Antifungal and cytotoxic action was also identified on this strain [47]; (iv) Streptomonomicin (STM) is an antibiotic lasso peptide from Streptomonospora alba YIM 90003, isolated from a soil sample in Xinjiang province, China. STM is active against several Gram-positive bacteria, in particular species of Bacillus, Listeria, Enterococcus, Mycobacterium and Staphylococcus. Despite that STM has an inhibitory action against a wide panel of Gram-positive pathogens, the activity against fungi and Gram-negative bacteria was not evidenced [48].

In addition to the mentioned genera of Actinobacteria (Nocardiopsis and Streptomyces), recognized as the more prolific producers of natural substances, other halophilic species belonging to different genera have also been described as producers of molecules like: (i) cyclic antimicrobial lipopeptides: Gramicidin S and four cyclic dipeptides (CDPs), named cyclo(L-4-OH-Pro-L-Leu), cyclo(L-Tyr-L-Pro), cyclo(L-Phe-L-Pro), and cyclo(L-Leu-L-Pro), were extracted from Paludifilum halophilum strain SMBg3, which constitute a new genus of the family Thermoactinomycetaceae, isolated from superficial sediment collected from Sfax marine solar saltern in Tunisia. These CDPs possess an inhibitory effect against the plant pathogen Agrobacterium tumefaciens and the human pathogens Staphylococcus aureus, Salmonella enterica, Escherichia coli, and Pseudomonas aeruginosa [49]; (ii) A semi synthetic derivative N-(4-aminocyclooctyl)-3,5-dinitrobenzamide, obtained from the precursor of the novel natural product cyclooctane-1,4-diamine and a known compound 3-([1H-indol-6-yl] methyl) hexahydropyrrolo [1,2-a] pyrazine-1,4-dione were obtained from Pseudonocardia endophytica VUK-10, isolated from sediment of Nizampatnam mangrove ecosystem in Bay of Bengal, India. The new compound, semi synthetic derivative $\mathrm{N}$-(4-aminocyclooctyl)-3,5-dinitrobenzamide showed a strong antimicrobial and antifungal activity against Streptococcus mutans, Pseudomonas aeruginosa, Candida albicans, and Aspergillus niger. Significant anticancer activities at nanomolar concentrations were also observed in carcinoma cell lines MDA-MB-231 (breast), HeLa (cervical), OAW-42 (ovarian), and MCF-7 (breast) reported as resistant to cancer drugs [50]. In minor grade, other halophilic bacteria not belonging to the phylum Actinobacteria produce antimicrobial compounds, as for example halophilic strains of the genus Vibrio, like Vibrio sp. A1SM3-36-8, isolated from Colombian solar salterns, which produces 13-cis-docosenamide with special antimicrobial action against Methicillin-resistant Staphylococcus aureus (MRSA) and cytotoxic activity against cervical adenocarcinoma (SiHa) and lung carcinoma (A-549) [51]. Within this genus, Vibrio parahaemolyticus strain B2 is recognized by producing Vibrindole A, and was also effective against Staphylococcus aureus [52].

Finally, Bacillus sp. BS3 [53] and Halomonas salifodinae MPM-TC [54] showed antimicrobial action against Pseudomonas aeruginosa. Both strains were isolated from solar salterns in Thamaraikulam, Tamil Nadu, India. In the case of Halomonas salifodinae MPM-TC, besides of the inhibition of bacterial growth also exhibits an antiviral action against the White Spot Syndrome Virus (WSSV) in the white shrimp Fenneropenaeus indicus. The effect suppressor of the virus and the boosting of immune system of the shrimps make of the extracted compound a feasible alternative to commercially banned antibiotics and excellent candidate to develop new antiviral drugs against shrimp viruses such as WSSV.

A genome-mining study conducted on 2699 genomes across the three domains of life demonstrated the widespread distribution of non-ribosomal peptide synthetase (NRPSs) and modular polyketide synthase (PKSs) biosynthetic pathways. Among 31 phyla of bacteria inferred, Actinobacteria is the most representative exhibiting the presence of 1225 gene clusters between NRPS, PKS and hybrids from a total of the 271 genomes studied. It was observed that Salinispora arenicola CNS-205 and Salinispora tropica CNB-440 harbor PKS and NRPS gene clusters, respectively. The halophilic bacterium Halomonas elongata DSM 2581 also contains NPRS [55]. 
Table 1. Chronological report of halophilic bacteria and their molecules with antimicrobial activity in vitro against human pathogens.

\begin{tabular}{|c|c|c|c|c|c|}
\hline Isolation Source & Genus & Antimicrobial Activity & Molecule & Formula & Reference \\
\hline \multirow{2}{*}{$\begin{array}{l}\text { Saline soil of Kovalam solar } \\
\text { salterns India }\end{array}$} & \multirow{2}{*}{ Nocardiopsis sp. AJ1 } & \multirow{2}{*}{$\begin{array}{l}\text { E. coli, } \\
\text { S. aureus, } \\
\text { P. aeruginosa, } \\
\text { V. parahaemolyticus, } \\
\text { A. hydrophila }\end{array}$} & $\begin{array}{l}\text { Pyrrolo (1,2-A (pyrazine-1,4-dione, } \\
\text { hexahydro-3-(2-methylpropyl)-) }\end{array}$ & $\mathrm{C}_{11} \mathrm{H}_{18} \mathrm{~N}_{2} \mathrm{O}_{2}$ & \multirow[b]{2}{*}[40]{} \\
\hline & & & Actinomycin C2 & $\mathrm{C}_{63} \mathrm{H}_{88} \mathrm{~N}_{12} \mathrm{O}_{16}$ & \\
\hline \multirow{7}{*}{ Sfax solar saltern, Tunisia } & \multirow{7}{*}{$\begin{array}{l}\text { Paludifilum halophilum } \\
\text { SMBg3 }\end{array}$} & \multirow{7}{*}{$\begin{array}{l}\text { E. coli BW25113, } \\
\text { S. henoxaz ATCC43972, } \\
\text { P. aeruginosa ATCC 49189 } \\
\text { Gram-positive M. luteus LB 14110, } \\
\text { S. aureus ATCC6538, and } \\
\text { L. ivanovii BUG 496) }\end{array}$} & Cyclic lipopeptide: & & \multirow{7}{*}{ [49] } \\
\hline & & & Gramicidin S & $\mathrm{C}_{60} \mathrm{H}_{92} \mathrm{~N}_{12} \mathrm{O}_{10}$ & \\
\hline & & & Cyclic dipeptides (CDPs): & & \\
\hline & & & Cyclo(L-4-OH-Pro-L-Leu) & $\mathrm{C}_{11} \mathrm{H}_{18} \mathrm{~N}_{2} \mathrm{O}_{3}$ & \\
\hline & & & Cyclo(L-Tyr-L-Pro) & $\mathrm{C}_{14} \mathrm{H}_{16} \mathrm{~N}_{2} \mathrm{O}_{3}$ & \\
\hline & & & Cyclo(L-Phe-L-Pro) & $\mathrm{C}_{14} \mathrm{H}_{16} \mathrm{~N}_{2} \mathrm{O}_{2}$ & \\
\hline & & & Cyclo(L-Leu-L-Pro) & $\mathrm{C}_{11} \mathrm{H}_{18} \mathrm{~N}_{2} \mathrm{O}_{2}$ & \\
\hline $\begin{array}{l}\text { Brine and sediments from } \\
\text { Manaure solar saltern. La } \\
\text { Guajira, Colombia }\end{array}$ & Vibrio sp. A1SM3-36-8 & $\begin{array}{l}\text { Methicillin-resistant } \\
\text { S. aureus (MRSA) ATCC BAA-44, } \\
\text { B. subtilis ATCC } 21556\end{array}$ & 13-cis-docosenamide & $\mathrm{C}_{22} \mathrm{H}_{43} \mathrm{NO}$ & [51] \\
\hline \multirow{3}{*}{$\begin{array}{l}\text { Salt lake soil, Algerian Sahara. } \\
\text { Algeria }\end{array}$} & \multirow{3}{*}{ Nocardiopsis sp. HR-4 } & \multirow{3}{*}{$\begin{array}{l}\text { S. aureus ATCC 25923, } \\
\text { Methicillin-Resistant } \\
\text { S. aureus (MRSA) ATCC 43300, } \\
\text { M. luteus ATCC 4698, } \\
\text { E. faecalis ATCC } 29212\end{array}$} & Angucyclines and angucyclinones: & & \multirow{3}{*}{ [41] } \\
\hline & & & $\begin{array}{l}\text { Compound 1: } \\
(-)-8-O-\text {-methyltetrangomycin }\end{array}$ & $\mathrm{C}_{20} \mathrm{H}_{16} \mathrm{O}_{5}$ & \\
\hline & & & $\begin{array}{l}\text { Compound 2: } \\
\text { (-)-7-deoxy-8-O methyltetrangomycin }\end{array}$ & $\mathrm{C}_{20} \mathrm{H}_{18} \mathrm{O}_{5}$ & \\
\hline \multirow{2}{*}{$\begin{array}{l}\text { Topsoil saltern in Jeungdo, } \\
\text { Jeollanam-do, Republic of } \\
\text { Korea }\end{array}$} & \multirow[t]{2}{*}{ Nocardiopsis sp. HYJ128 } & \multirow{2}{*}{ Salmonella enterica ATCC 14028} & Borrelidin C & $\mathrm{C}_{28} \mathrm{H}_{43} \mathrm{NO}_{7}$ & \multirow{2}{*}{ [42] } \\
\hline & & & Borrelidin D & $\mathrm{C}_{28} \mathrm{H}_{43} \mathrm{NO}_{7}$ & \\
\hline $\begin{array}{l}\text { Sediments of mangrove } \\
\text { Nizampatnam, Bay of Bengal, } \\
\text { Andhra Pradesh, India }\end{array}$ & $\begin{array}{l}\text { Pseudonocardia endophytica } \\
\text { VUK-10 }\end{array}$ & $\begin{array}{l}\text { B. cereus (MTCC 430), } \\
\text { S. mutans (MTCC 497), } \\
\text { S. aureus (MTCC 3160), } \\
\text { S. epidermis (MTCC 120), } \\
\text { B. subtilis (ATCC 6633), } \\
\text { B. megaterium (NCIM 2187), } \\
\text { E. coli (ATCC 35218), } \\
\text { P. aeruginosa (ATCC 9027), } \\
\text { P. vulgaris (MTCC 7299), } \\
\text { S. marcescens (MTCC 118), } \\
\text { X. campestris (MTCC 2286), } \\
\text { X. malvacearum (NCIM 2954) } \\
\text { and S. typhi (ATCC 14028) }\end{array}$ & $\begin{array}{l}\text { 3-((1H-indol-6-yl) methyl) } \\
\text { hexahydropyrrolo }[1,2 \text {-a] pyrazine-1,4-dione }\end{array}$ & $\mathrm{C}_{15} \mathrm{H}_{20} \mathrm{~N}_{4} \mathrm{O}_{5}$ & {$[50]$} \\
\hline
\end{tabular}


Table 1. Cont.

\begin{tabular}{|c|c|c|c|c|c|}
\hline Isolation Source & Genus & Antimicrobial Activity & Molecule & Formula & Reference \\
\hline $\begin{array}{l}\text { Soil sample, Xinjiang Province, } \\
\text { China }\end{array}$ & $\begin{array}{l}\text { Streptomonospora alba YIM } \\
90003\end{array}$ & $\begin{array}{l}\text { B. anthracis, } \\
\text { B. halodurans, } \\
\text { B. cereus ATCC 4342, ATCC 13472, } \\
\text { B. subtilis, } \\
\text { L. monocytogenes, } \\
\text { E. faecalis, } \\
\text { S. aureus } \\
\text { and M. smegmatis }\end{array}$ & Streptomonomicin (STM) & $\mathrm{C}_{107} \mathrm{H}_{160} \mathrm{~N}_{22} \mathrm{O}_{30}$ & [48] \\
\hline \multirow{3}{*}{$\begin{array}{l}\text { Great Barrier Reef (GBR) } \\
\text { sponges, Queensland, } \\
\text { Australia }\end{array}$} & \multirow{3}{*}{ Salinisporaarenicola } & \multirow{3}{*}{$\begin{array}{l}\text { M. avium, } \\
\text { M. leprae, } \\
\text { M. lepromatosis, } \\
\text { M. tuberculosis }\end{array}$} & Rifamycin B & $\mathrm{C}_{39} \mathrm{H}_{49} \mathrm{NO}_{14}$ & \multirow{3}{*}{ [56] } \\
\hline & & & Rifamycin S & $\mathrm{C}_{37} \mathrm{H}_{45} \mathrm{NO}_{12}$ & \\
\hline & & & Rifamycin W & $\mathrm{C}_{35} \mathrm{H}_{45} \mathrm{NO}_{11}$ & \\
\hline \multirow{6}{*}{$\begin{array}{l}\text { Saline soil, Qaidam Basin, } \\
\text { north-west China }\end{array}$} & \multirow{6}{*}{$\begin{array}{l}\text { Nocardiopsis terrae YIM } \\
90022\end{array}$} & \multirow{6}{*}{$\begin{array}{l}\text { S. aureus, } \\
\text { E. coli } \\
\text { and B. subtilis }\end{array}$} & $\begin{array}{l}\text { Quinoloid alkaloid } \\
\text { 4-oxo-1,4-dihydroquinoline-3-carboxamide }\end{array}$ & $\mathrm{C}_{10} \mathrm{H}_{7} \mathrm{~N}_{2} \mathrm{O}_{2}$ & \multirow{6}{*}{ [43] } \\
\hline & & & $p$-hydroxybenzoic acid & $\mathrm{C}_{7} \mathrm{H}_{6} \mathrm{O}_{3}$ & \\
\hline & & & $\mathrm{N}$-acetyl-anthranilic acid & $\mathrm{C}_{9} \mathrm{H}_{9} \mathrm{NO}$ & \\
\hline & & & Indole-3-carboxylic acid & $\mathrm{C}_{9} \mathrm{H}_{7} \mathrm{NO}_{2}$ & \\
\hline & & & Cyclo (Trp-Gly) & $\mathrm{C}_{13} \mathrm{H}_{13} \mathrm{~N}_{3} \mathrm{O}_{2}$ & \\
\hline & & & Cyclo (Leu-Ala) & $\mathrm{C}_{9} \mathrm{H}_{16} \mathrm{~N}_{2} \mathrm{O}_{2}$ & \\
\hline \multirow{8}{*}{$\begin{array}{l}\text { Condenser water, solar salt } \\
\text { works in Thamaraikulam, } \\
\text { Kanyakumari district, Tamil } \\
\text { Nadu, India }\end{array}$} & \multirow{8}{*}{ Bacillus sp. BS3 } & \multirow{8}{*}{$\begin{array}{l}\text { E. coli, } \\
\text { S. aureus, } \\
\text { P. aeruginosa } \\
\text { and S. typhi }\end{array}$} & Lipopeptide biosurfactants & & \multirow{8}{*}{ [53] } \\
\hline & & & 13-Docosenamide, $(\mathrm{Z})$ & $\mathrm{CH}_{3}\left(\mathrm{CH}_{2}\right)_{7} \mathrm{CH}=\mathrm{CH}\left(\mathrm{CH}_{2}\right)_{11} \mathrm{CONH}_{2}$ & \\
\hline & & & Mannosamine & $\mathrm{C}_{6} \mathrm{H}_{13} \mathrm{NO}_{5} \cdot \mathrm{HCl}$ & \\
\hline & & & 9-Octadecenamide, $(\mathrm{Z})$ & $\mathrm{C}_{18} \mathrm{H}_{35} \mathrm{NO}$ & \\
\hline & & & 2-Octanol, 2-methyl-6-methylene & $\mathrm{C}_{12} \mathrm{H}_{22} \mathrm{O}_{2}$ & \\
\hline & & & Cylohex-1,4,5-triol-3-one-1-carbo & $\mathrm{C}_{5} \mathrm{H}_{8} \mathrm{FN}_{3}$ & \\
\hline & & & 2-Butanamine, 2-methyl- & $\mathrm{C}_{5} \mathrm{H}_{13} \mathrm{~N}$ & \\
\hline & & & 1,2-Ethanediamine, $N, N, N^{\prime}, N^{\prime}$-tetramethyl- & $\mathrm{C}_{6} \mathrm{H}_{16} \mathrm{~N}_{2}$ & \\
\hline \multirow{2}{*}{$\begin{array}{l}\text { Hypersaline soil, Xinjiang, } \\
\text { China }\end{array}$} & \multirow{2}{*}{$\begin{array}{l}\text { Nocardiopsis gilva YIM } \\
90087\end{array}$} & \multirow{2}{*}{$\begin{array}{l}\text { B. subtilis, } \\
\text { S. aureus }\end{array}$} & $\begin{array}{l}p \text {-Terphenyl: } \\
6^{\prime} \text {-Hydroxy-4, } 2^{\prime}, 3^{\prime}, 4^{\prime \prime} \text {-tetramethoxy-p-terphenyl }\end{array}$ & $\mathrm{C}_{22} \mathrm{H}_{22} \mathrm{O}_{5}$ & \multirow[b]{2}{*}{ [44] } \\
\hline & & & $\begin{array}{l}p \text {-Terphenyl derivative: } \\
\text { 4,7-bis(4-methoxyphenyl)-6-hydroxy- } \\
\text { 5-methoxybenzo[d]thiazole }\end{array}$ & $\mathrm{C}_{22} \mathrm{H}_{19} \mathrm{NO}_{4} \mathrm{~S}$ & \\
\hline
\end{tabular}


Table 1. Cont.

\begin{tabular}{|c|c|c|c|c|c|}
\hline Isolation Source & Genus & Antimicrobial Activity & Molecule & Formula & $\begin{array}{l}\text { Reference } \\
\end{array}$ \\
\hline \multirow{6}{*}{$\begin{array}{l}\text { Solar salt condenser, } \\
\text { Thamaraikulam solar saltern, } \\
\text { Kanyakumari district, Tamil } \\
\text { Nadu, India }\end{array}$} & \multirow{6}{*}{$\begin{array}{l}\text { Halomonas salifodinae } \\
\text { MPM-TC }\end{array}$} & \multirow{6}{*}{$\begin{array}{l}\text { V. harveyi, } \\
\text { V. parahaemolyticus, } \\
\text { P. aeruginosa } \\
\text { and A. hydrophila }\end{array}$} & Perfluorotributylamine & $\mathrm{C}_{12} \mathrm{~F}_{27} \mathrm{~N}$ & \multirow{6}{*}{ [54] } \\
\hline & & & Cyclopentane, 1-butyl-2-ethyl- & $\mathrm{C}_{11} \mathrm{H}_{22}$ & \\
\hline & & & 1,1'-Biphenyl]-3-amine & $\mathrm{C}_{12} \mathrm{H}_{11} \mathrm{~N}$ & \\
\hline & & & Hexadecane, 2-methyl- & $\mathrm{C}_{17} \mathrm{H}_{36}$ & \\
\hline & & & Nonadecane & $\mathrm{C}_{19} \mathrm{H}_{40}$ & \\
\hline & & & Phytol & $\mathrm{C}_{20} \mathrm{H}_{40} \mathrm{O}$ & \\
\hline $\begin{array}{l}\text { Seashore soil, Bigeum Island, } \\
\text { South West coast of South } \\
\text { Korea }\end{array}$ & $\begin{array}{l}\text { Streptomyces hygroscopicus } \\
\text { BDUS } 49\end{array}$ & $\begin{array}{l}\text { B. subtilis, } \\
\text { S. aureus, } \\
\text { E. coli, } \\
\text { S. typhi }\end{array}$ & 7-Demethoxy rapamycin & $\mathrm{C}_{50} \mathrm{H}_{75} \mathrm{NO}_{12}$ & [47] \\
\hline \multirow[b]{5}{*}{$\begin{array}{l}\text { Marine sediment of Mission } \\
\text { Bay, San Diego, South } \\
\text { California }\end{array}$} & \multirow[b]{5}{*}{ Marinispora sp. NPS12745 } & S. aureus ATCC 29213-MSSA, & Chlorinated bisindole pirroles: & & \multirow[b]{5}{*}{ [57] } \\
\hline & & $\begin{array}{l}\text { S. aureus ATCC } 43300-\mathrm{MRSA} \text {, } \\
\text { S. epidermidis ATCC } 700578 \text {, }\end{array}$ & Lynamicin A & $\mathrm{C}_{22} \mathrm{H}_{16} \mathrm{~N}_{3} \mathrm{O}_{2} \mathrm{Cl}_{2}$ & \\
\hline & & & Lynamicin B & $\mathrm{C}_{22} \mathrm{H}_{14} \mathrm{~N}_{3} \mathrm{O}_{2} \mathrm{Cl}_{3} \mathrm{Na}$ & \\
\hline & & S. epidermidis ATCC 700582, & Lynamicin C & $\mathrm{C}_{20} \mathrm{H}_{12} \mathrm{~N}_{3} \mathrm{Cl}_{4}$ & \\
\hline & & $\begin{array}{l}\text { S. pneumoniae ATCC 49619-Penicillin } \\
\text { sensitive, } \\
\text { S. pneumoniae ATCC 51915-Penicillin } \\
\text { resistant, } \\
\text { E. faecalis ATCC 29212-Vancomycin sensitive, } \\
\text { E. faecium ATCC 700221-Vancomycin } \\
\text { resistant, } \\
\text { Haemophilus influenzae ATCC } 49247, \\
\text { Haemophilus influenzae ATCC } 49766 \\
\text { E. coli permeable mutant }\end{array}$ & Lynamicin D & $\mathrm{C}_{24} \mathrm{H}_{18} \mathrm{~N}_{3} \mathrm{O}_{4} \mathrm{Cl}_{2}$ & \\
\hline $\begin{array}{l}\text { Platinum Coast on the } \\
\text { Mediterranean Sea, north of } \\
\text { Egypt }\end{array}$ & Streptomyces sp. Merv8102 & $\begin{array}{l}\text { E. coli ATCC 10536, } \\
\text { P. aeruginosa ATCC 10145), } \\
\text { B. subtilis ATCC 6051, } \\
\text { S. aureus ATCC 6538 } \\
\text { and M. luteus ATCC } 9341\end{array}$ & $\begin{array}{l}\text { Essramycin } \\
\text { Triazolopyrimidine } \\
{[1,2,4] \text { Triazolo[1,5-2]pyrimidin-7(4H)-one, }} \\
\text { 5-methyl-2-(2-oxo-2-phenylethyl)- }\end{array}$ & $\mathrm{C}_{14} \mathrm{H}_{12} \mathrm{~N}_{4} \mathrm{O}_{2}$ & [58] \\
\hline \multirow{2}{*}{$\begin{array}{l}\text { Marine sediment, La Jolla, } \\
\text { California }\end{array}$} & \multirow[t]{2}{*}{ Streptomyces sp. CNQ-418 } & \multirow{2}{*}{ Methicillin-resistant S. aureus (MRSA) } & Marinopyrroles A & $\mathrm{C}_{22} \mathrm{H}_{12} \mathrm{Cl}_{4} \mathrm{~N}_{2} \mathrm{O}_{4}$ & \multirow{2}{*}{ [59] } \\
\hline & & & Marinopyrroles B & $\mathrm{C}_{22} \mathrm{H}_{11} \mathrm{BrCl}_{4} \mathrm{~N}_{2} \mathrm{O}_{4}$ & \\
\hline
\end{tabular}


Table 1. Cont

\begin{tabular}{|c|c|c|c|c|c|}
\hline Isolation Source & Genus & Antimicrobial Activity & Molecule & Formula & Reference \\
\hline $\begin{array}{l}\text { Sediment of Bay of Bengal, } \\
\text { India }\end{array}$ & $\begin{array}{l}\text { Streptomyces chibaensis sp. } \\
\text { AUBN1/7 }\end{array}$ & $\begin{array}{l}\text { B. subtilis ATCC } 6633, \\
\text { B. pumilus ATCC 19164, } \\
\text { S. aureus ATCC 29213, } \\
\text { E. coli ATCC 25922, } \\
\text { P. aeruginosa ATCC } 27853 \\
\text { P. vulgaris ATCC } 6897\end{array}$ & 1-Hydroxy-1-norresistomycin & $\mathrm{C}_{21} \mathrm{H}_{14} \mathrm{O}_{7}$ & [45] \\
\hline \multirow{2}{*}{$\begin{array}{l}\text { Sediment of the Lagoon de } \\
\text { Terminos at the Gulf of Mexico }\end{array}$} & \multirow{2}{*}{$\begin{array}{l}\text { Streptomyces } \\
\text { B8005Streptomyces B4842 }\end{array}$} & \multirow{2}{*}{$\begin{array}{l}\text { E. coli, } \\
\text { S. aureus, } \\
\text { S. viridochromogenes }\end{array}$} & $\begin{array}{l}\text { Resistomycin } \\
\text { 1-Hydroxy-1-norresistomycin }\end{array}$ & $\mathrm{C}_{21} \mathrm{H}_{14} \mathrm{O}_{7}$ & \multirow[b]{2}{*}{ [60] } \\
\hline & & & $\begin{array}{l}\text { Resistoflavin } \\
\text { Resistoflavin methyl ether }\end{array}$ & $\mathrm{C}_{23} \mathrm{H}_{18} \mathrm{O}_{7}$ & \\
\hline $\begin{array}{l}\text { Marine sediment from Scripps } \\
\text { Canyon. La Jolla, California, } \\
\text { Pacific Coast, United States }\end{array}$ & $\begin{array}{l}\text { Streptomyces nodosus } \\
\text { NPS007994 }\end{array}$ & $\begin{array}{l}\text { Drug-sensitive and drug-resistant } \\
\text { Gram-positive reaction bacteria }\end{array}$ & $\begin{array}{l}\text { Lajollamycin } \\
\text { Nitro-tetraene Spiro- } \beta \text {-lactone- } \gamma \text {-lactam }\end{array}$ & $\mathrm{C}_{36} \mathrm{H}_{53} \mathrm{~N}_{3} \mathrm{O}_{10}$ & [61] \\
\hline \multirow{3}{*}{$\begin{array}{l}\text { Sediment of Jiaozhou Bay, } \\
\text { China }\end{array}$} & \multirow{3}{*}{ Actinomadura sp. M048 } & \multirow{3}{*}{$\begin{array}{l}\text { S. aureus, } \\
\text { B. subtilis, } \\
\text { and S. viridochromogenes }\end{array}$} & $\begin{array}{l}\text { Chandrananimycin A } \\
\text { Acetamide, } \\
\text { N-(9-hydroxy-3-oxo-3H-phenoxazin-2-yl)- }\end{array}$ & $\mathrm{C}_{14} \mathrm{H}_{10} \mathrm{~N}_{2} \mathrm{O}_{4}$ & \multirow{3}{*}{ [62] } \\
\hline & & & $\begin{array}{l}\text { Chandrananimycin B } \\
\text { Acetamide, } \\
\text { 2-hydroxy-N-(3-oxo-3H-phenoxazin-2-yl)- }\end{array}$ & $\mathrm{C}_{14} \mathrm{H}_{10} \mathrm{~N}_{2} \mathrm{O}_{4}$ & \\
\hline & & & $\begin{array}{l}\text { Chandrananimycin C } \\
\text { 1-Methoxy-3-methyl-1,2,3,4-tetrahydro-5H-pyrido[3,2 } \\
\text { a]phenoxazin-5-one }\end{array}$ & $\mathrm{C}_{17} \mathrm{H}_{16} \mathrm{~N}_{2} \mathrm{O}_{3}$ & \\
\hline \multirow{3}{*}{$\begin{array}{l}\text { Sandy sediment, coastal site of } \\
\text { Mauritius, Indian Ocean }\end{array}$} & \multirow{3}{*}{ Streptomyces sp. B6921 } & \multirow{3}{*}{$\begin{array}{l}\text { S. aureus, } \\
\text { E. coli, } \\
\text { B. subtilis, } \\
\text { and S. viridochromogenes }\end{array}$} & Fridamycin D & $\mathrm{C}_{31} \mathrm{H}_{32} \mathrm{O}_{12}$ & \multirow{3}{*}{ [46] } \\
\hline & & & Himalomycin A & $\mathrm{C}_{43} \mathrm{H}_{52} \mathrm{O}_{16}$ & \\
\hline & & & Himalomycin B & $\mathrm{C}_{43} \mathrm{H}_{56} \mathrm{O}_{16}$ & \\
\hline $\begin{array}{l}\text { Mucus secreted by the box- } \\
\text { fish Ostracion cubicus, Israel }\end{array}$ & Vibrio parahaemolyticus B2 & $\begin{array}{l}\text { S. aureus, } \\
\text { S. albus } \\
\text { and B. subtilis }\end{array}$ & Vibrindole A & $\mathrm{C}_{18} \mathrm{H}_{16} \mathrm{~N}_{2}$ & [52] \\
\hline
\end{tabular}


Table 2. Chronological report of bacteria with antimicrobial activity in vitro against human pathogens which molecules have not been chemically identified.

\begin{tabular}{|c|c|c|c|}
\hline Isolation Source & Genus & Antimicrobial Activity & Reference \\
\hline Khewra Salt Range, Punjab, Pakistan & $\begin{array}{l}\text { Aquisalibacillus elongatus MB592, } \\
\text { Salinicoccus sesuvii MB597, } \\
\text { and Halomonas aquamarina MB598 }\end{array}$ & $\begin{array}{l}\text { B. subtilis, } \\
\text { B. pumilus, } \\
\text { E. faecalis, } \\
\text { B. cereus, } \\
\text { K. pneumoniae, } \\
\text { Alcaligenes faecalis, } \\
\text { P. geniculata, } \\
\text { E. faecium }\end{array}$ & [63] \\
\hline $\begin{array}{l}\text { Hypersaline soils (solonchaks, solonetz and takyr) from } \\
\text { Kostanay, Auliekol and Mendykara. Almaty region, Balkhash, } \\
\text { Kazakhstan }\end{array}$ & Actinomycetes spp. & $\begin{array}{l}\text { S. aureus MRSA, } \\
\text { E. coli (pMG223) }\end{array}$ & [64] \\
\hline Marine water, Gujarat, Western India & Kocuria sp. strain rsk4 & Antibiotic-resistant S. aureus & [65] \\
\hline \multirow{4}{*}{ Crystallizer pond sediments of Ribandar saltern, Goa, India } & Streptomyces radiopugnans & $\begin{array}{l}\text { S. typhimurium, } \\
\text { P. vulgaris, } \\
\text { E. coli }\end{array}$ & \multirow{4}{*}{ [66] } \\
\hline & Streptomyces sporocinereus & S. typhimurium, P. vulgaris, E. coli & \\
\hline & Kocuria palustris & S. aureus & \\
\hline & Micromonospora sp. & V. cholerae & \\
\hline $\begin{array}{l}\text { Sediment of estuarine coastal brackish, Chilika Lake, Khurdha } \\
\text { Odisha, India }\end{array}$ & Streptomyces chilikensis RC 1830 & $\begin{array}{l}\text { E. coli, } \\
\text { S. aureus, } \\
\text { B. cereus } \\
\text { and S. typhi }\end{array}$ & [67] \\
\hline Mangrove sediment of Visakhapatnam, Andhra Pradesh, India & Streptomyces sp. & $\begin{array}{l}\text { S. aureus, } \\
\text { B. subtilis, } \\
\text { B. cereus, } \\
\text { E. coli, } \\
\text { P. aeruginosa, } \\
\text { P. vulgaris } \\
\end{array}$ & [68] \\
\hline Mangrove sediment, Nizampatnam, Andhra Pradesh, India & Pseudonocardia VUK-10 & $\begin{array}{l}\text { S. aureus, } \\
\text { S. mutans, } \\
\text { B. subtilis, } \\
\text { E. coli, } \\
\text { E. faecalis, } \\
\text { P. aeruginosa }\end{array}$ & [69] \\
\hline
\end{tabular}


Table 2. Cont.

\begin{tabular}{|c|c|c|c|}
\hline Isolation Source & Genus & Antimicrobial Activity & Reference \\
\hline Salt pans Batim and Ribandar, Goa, India & $\begin{array}{l}\text { Bacillus spp. } \\
\text { Virgibacillus spp. }\end{array}$ & $\begin{array}{l}\text { A. baumanii,, } \\
\text { A. hydrophila, } \\
\text { Citrobacter diversus, } \\
\text { Citrobacter freundii, } \\
\text { E. coli ATCC 25922, } \\
\text { K. pneumoniae, } \\
\text { Morganella morganii, } \\
\text { P. mirabilis, } \\
\text { P. ATCC 27855, } \\
\text { P. spp., } \\
\text { S. paratyphi A, } \\
\text { S. typhi, } \\
\text { S. typhimurium, } \\
\text { S. boydii, S. flexneri, } \\
\text { V. cholerae, } \\
\text { Methicillin Resistant S. aureus (MRSA), } \\
\text { Methicillin Sensitive S. aureus (MSSA), } \\
\text { S. aureus ATCC 25923, } \\
\text { S. citreus }\end{array}$ & [70] \\
\hline Salt pans, Kodiakarai, Tamil Nadu, India & Streptoverticillium album & S. aureus, K. pneumoniae and E. coli & [71] \\
\hline
\end{tabular}


Table 2. Cont.

\begin{tabular}{|c|c|c|c|}
\hline Isolation Source & Genus & Antimicrobial Activity & Reference \\
\hline Crystallizer pond, Madurai, India & Nocardiopsis sp. JAJ16 & $\begin{array}{l}\text { S. aureus, } \\
\text { B. subtilis, } \\
\text { S. typhi, } \\
\text { Methicillin-resistant S. aureus (MRSA), } \\
\text { K. pneumoniae, } \\
\text { Enterobacter sp. } \\
\text { and P. aeruginosa }\end{array}$ & [73] \\
\hline Bay of Bengal coast of Puducherry and Marakkanam, India & Streptomyces sp. VITSVK9 & $\begin{array}{l}\text { B. subtilis, } \\
\text { Escherchia coli, } \\
\text { K. pneumoniae, } \\
\text { S. aureus } \\
\text { and S. species }\end{array}$ & [74] \\
\hline $\begin{array}{l}\text { Marine sediment of Marakkanam, Bay of Bengal Coast, Tamil } \\
\text { Nadu. India }\end{array}$ & Saccharopolyspora salina VITSDK4 & $\begin{array}{l}\text { S. aureus ATCC 25923, } \\
\text { B. subtilis ATCC 6633, } \\
\text { E. coli ATCC 25922, } \\
\text { K. pneumoniae ATCC } 10273 \\
\end{array}$ & [75] \\
\hline Marakkanam coast of Tamil Nadu, India & Streptomyces sp. VITSDK1 & $\begin{array}{l}\text { S. aureus ATCC 25923, } \\
\text { B. subtilis ATCC 6633, } \\
\text { E. coli ATCC 25922, } \\
\text { K. pneumoniae ATCC } 10273\end{array}$ & [76] \\
\hline $\begin{array}{l}\text { Water samples Asen fjord in the Trondheim fjord and } \\
\text { Steinvikholmen, Norway }\end{array}$ & Streptomyces sp. & Gram-negative and Gram-positive bacteria & [79] \\
\hline Salt Lake Bardawil, Egypt & Streptomyces viridiviolaceus & $\begin{array}{l}\text { E. coli, } \\
\text { Edwardsiella tarda, } \\
\text { Corynebacterium michiganese B-33, } \\
\text { P. solanacearum B-3212 } \\
\text { and Staphilococcus spp. }\end{array}$ & [77] \\
\hline
\end{tabular}


Table 2. Cont.

\begin{tabular}{|c|c|c|c|}
\hline Isolation Source & Genus & Antimicrobial Activity & Reference \\
\hline $\begin{array}{l}\text { Soil from salt pan regions of Cuddalore and Parangipettai } \\
\text { (Porto-Novo). Tamil Nadu, India }\end{array}$ & $\begin{array}{l}\text { Streptomyces sp., } \\
\text { Saccharomonospora sp. }\end{array}$ & $\begin{array}{l}\text { E. coli, } \\
\text { K. pneumoniae, } \\
\text { P. aeruginosa, } \\
\text { V. cholerae, } \\
\text { S. typhi, } \\
\text { S. aureus, } \\
\text { and S. dysenteriae }\end{array}$ & [80] \\
\hline Bismarck and Solomon Sea off the coast of Papua New Guinea & $\begin{array}{l}\text { Micromonospora nigra DSM 43818, } \\
\text { Micromonospora rhodorangea, } \\
\text { Micromonospora halophytica DSM } 43171\end{array}$ & $\begin{array}{l}\text { Multidrug-resistant (MDR) Gram-positive } \\
\text { pathogens, vancomycin-resistant enterococci } \\
\text { (VRE), and methicillin-resistant } \text { S. aureus } \\
\text { (MRSA) }\end{array}$ & [81] \\
\hline Marine sediment, Alibag coast, Maharashtra, India & $\begin{array}{l}\text { Actinopolyspora spp. AH1, } \\
\text { A.halophila, } \\
\text { A. mortivallis, } \\
\text { A. iraqiensis }\end{array}$ & $\begin{array}{l}\text { S. aureus, } \\
\text { S. epidermidis, } \\
\text { B. subtilis }\end{array}$ & [82] \\
\hline
\end{tabular}

Noted: American Type Culture Collection (ATCC); Deutsche Sammlung von Mikroorganismen und Zellkulturen (DSMZ); Multidrug-resistant (MDR); Microbial Type Culture Collection and Gene Bank (MTCC). Microorganisms: Acinetobacter (A.): A. baumanii. Aeromonas (A.): A. hydrophila. Alcaligenes (A.): A. faecalis. Bacillus (B.): B. cereus, B. halodurans, B. megaterium, B. pumilus, B. subtilis. Burkholderia (B.): B. metallica. Candida (C.): C. albicans. Citrobacter (C.): C. diversus, C. freundii. Corynebacterium (C.): C. michiganese. Edwardsiella (E.): E. tarda. Enterobacter (E.): E. aerogenes. Enterococcus (E.): E. faecalis, E. faecium, Vancomycin resistant Enterococcus faecium (VREF), Vancomycin sensitive Enterococcus faecalis (VSEF), Vancomycin resistant enterococci (VRE). Escherichia (E.): E. coli. Haemophilus (H.): H. influenzae. Klebsiella (K.): K. pneumonia. Listeria (L.): L. ivanovii, L. monocytogenes. Micrococcus (M.): M. luteus. Morganella (M.): M. morganii. Mycobacterium (M.): M. avium, M. leprae, M. lepromatosis, M. smegmatis, M. tuberculosis. Proteus (P.): P. mirabilis, P. vulgaris. Pseudomonas (P.): P. aeruginosa, P. geniculata, P. solanacearum. Salmonella (S.): S. henoxaz, S. paratyphi, S. typhi, S. typhimurium. Serratia (S.): S. marcescens. Shigella (S.): S. boydii, S. dysenteriae, S. flexneri. Staphylococcus (S.): S. aureus, S. citreus, solanacearum. Salmonella (S.): S. henoxaz, S. paratyphi, S. typhi, S. typhimurium. Serratia (S.): S. marcescens. Shigella (S.): S. boydii, S. dysenteriae, S. flexneri. Staphylococcus (S.): S. aureus, S. citreus,
S. epidermidis, Antibiotic-resistant Staphylococcus aureus (ARSA), Methicillin Sensitive Staphylococcus aureus (MSSA), Methicillin-resistant Staphylococcus aureus (MRSA). Streptococcus (S.): S. mutans, S. pneumoniae, Penicillin resistant Streptococcus pneumoniae (PRSP), Penicillin sensitive Streptococcus pneumoniae (SPPS). Streptomyces (S.): S. viridochromogenes. Vibrio (V.): V. cholerae, V. harveyi, V. parahaemolyticus. Xanthomonas (X.): X. campestris, X. malvacearum. 
The biotechnological potential of halophilic bacteria, especially for antimicrobial exploitation, still remains in progress, in spite that the occurrence of new several groups of microorganisms is high, the rate of discovery of new biomolecules is low compared with non-halophilic bacteria. Despite periodic descriptions of new species and attempts to culture hidden microbiota, there are no significant studies focused on the discovery of new bioactive metabolites produced by microorganisms from hypersaline ecosystems. The genome-guided studies are currently the best support to take novel strategies in drug discovery. All the antimicrobial compounds described herein derived from halophilic bacteria in which the molecule has been elucidated are summarized in Table 1 and the strains capable of inhibiting pathogens in primary tests whose molecules are unknown are shown in Table 2.

\subsection{Archaea}

Since the discovery of halocins and their action against the surrounding microbiota in their habitats [35] no new or known antimicrobial compounds derived from archaea capable of inhibiting human pathogens have been reported in the literature to date. At an ecological level, the role of archaeocins in microbial communities is the interspecies competition, the antimicrobial activity of halocins suggests that its function is to dominate a given niche occupied by microorganisms having similar adaptations and nutritional requirements [83-85]. Members of Halorubrum and Haloferax have been identified as the preponderant halocin-producing genera, the cross-domanin antimicrobial action was observed against bacterial members of the genera Halomonas, Rhodovibrio, Salisaeta, or Pontibacillus, all isolated from hypersaline samples [86].

To understand the current situation, it is necessary that a comprehensive analysis of the possible reasons why haloarchaea are under-explored at the biotechnological level and why the antimicrobial exploitation is scarce in comparison with other microorganisms prevenient of non-halophilic environments. The first limitation found is the cultivation time of haloarchaea, observed at around 5 to 30 days to yield colonies or cellular density in broth cultures [12]. Once the cultivation is reached, the upcoming drawback is the evaluation of the inhibitory capacity of haloarchaea against a panel of human pathogens. The main obstacle to overcome is when the primary screening (isolate vs. pathogen) is performed due to the high salinity requirements of haloarchaea to grow, greater than $20 \%$ of $\mathrm{NaCl}$ until saturation, while in halophilic bacteria the screening can be adapted at lower range of salinity, under $15 \%$ of $\mathrm{NaCl}$.

Tests such a direct spot-inoculation of the supernatant, diffusion discs, and cross-streak require the adaptation of an appropriate protocol. Finding the same and suitable conditions to test both microorganisms drive to set-up alternative technical procedures, like dual-media and crude extracts for testing those strains growing above the seawater salinity, ca. $3.5 \%$ [87]. Another possible reason is that the study of extremophilic microbiota has been approached at an ecological level and the vast biotechnological exploitation of these extremophiles is more recognized on their enzymes and compatible solutes. The low metabolic requirements, the hypersaline conditions where they thrive, or the low competition for nutrients with their peers determine their behavior, i.e., the production of halocins, which action is limited to the closest members inhabiting in the same environment [88,89]. This could explain that the production of antimicrobials against the non-halophilic community of microorganisms seems to be unnecessary.

Constituted as a powerful tool, "omics" approaches as metagenomics and genomics effectively support ecological and bioprospecting studies deciphering new insights into halophilic microorganisms [90-92]. Extremely rare is the interdomain horizontal gene transfer (IHGT) across bacteria, archaea, and fungi of homologous DNA. However, a genomic-guided study revealed for the first time a potent antibacterial gene encoding a glycosyl hydrolase 25 muramidases (GH25-muramidase) identified in archaea after co-cultivation with a bacterial competitor [93]. In the genome-mining study conducted by Wang et al. (2014), an atlas of nonribosomal peptide synthetase (NRPSs) and modular polyketide synthase (PKSs) gene clusters was built based on 2699 genomes of bacteria, archaea, and fungi. In this study, were included 25 members of Halobacteria: Haloarcula hispanica ATCC 33960, 
Halalkalicoccus jeotgali B3, Haloarcula marismortui ATCC 43049, Halobacterium sp. NRC-1, Halobacterium salinarum R1, Haloferax mediterranei ATCC 33500, Haloferax volcanii DS2, Halogeometricum borinquense DSM 11551, Halomicrobium mukohataei DSM 12286, Halopiger xanaduensis SH-6, Haloquadratum walsbyi C23, Haloquadratum walsbyi DSM 16790, Halorhabdus tiamatea SARL4B, Halorhabdus utahensis DSM 12940, Halorubrum lacusprofundi ATCC 49239, Haloterrigena turkmenica DSM 5511, Halovivax ruber XH-70, Natrialba magadii ATCC 43099, Natrinema sp. J7-2, Natrinema pellirubrum DSM 15624, Natronobacterium gregoryi SP2, Natronococcus occultus SP4, Natronomonas moolapensis 8.8.11, Natronomonas pharaonis DSM 2160, Salinarchaeum sp. Harcht-Bsk1. Of a total of 3339 cataloged gene clusters, no PKS, NPKS or hybrid in Halobacteria were reported. Within the studied archaea, only two and one NRPS were identified in Methanobacteria and Methanomicrobia, respectively [55]. Despite these results and considering that the class Halobacteria is wide represented with seven families, these results do not exclude the biosynthetic capacity of nonribosomal peptide and polyketide, and nor discourage the biotechnological interest of haloarchaea for future natural product discovery.

\subsection{Fungi}

Along the years of research on natural products, fungi represent the basis of antimicrobial discovery. Halotolerant and halophilic fungal communities that inhabit the natural hypersaline environments are not strictly salt requiring, as they can grow and adjust to the whole salinity range, from freshwater to almost saturated $\mathrm{NaCl}$ solutions [94,95]. Despite this versatility, the vast majority of antimicrobial molecules from halophilic fungi have been produced under low or moderate salinity conditions since the primary screenings against SKAPE microorganisms are easier without $\mathrm{NaCl}$. The mycobiota of hypersaline environments is dominated by members of Aspergillus, Penicillium, and other genera, such as Alternaria, Cladosporium, Fusarium, Debaryomyces, Scopulariopsis, Chaetomium, Wallemia, and Hortaea, which are well represented in ecological and biodiversity studies [96,97]. The species Gymnoascus halophilus, Aspergillus penicillioides, Hortaea werneckii, Phaeotheca triangularis, Aureobasidium pullulans, Trimmatostroma salinum, and some species of the genus Wallemia, like W. ichthyophaga, are recognized as obligately halophilic, or require high levels of salt above that of seawater [98,99]. However, antimicrobial compounds have not been reported from these species.

The halophilic species of the genus Aspergillus are the most prolific and several strains of Aspergillus sp. have been isolated from Arctic sub-sea sediments from the Barents Sea (Table 3). In particular, strain $8 \mathrm{Na}$ identified as $A$. protuberus, a polyextremophilic fungus able to grow in a wide range of $\mathrm{pH}$, temperature and salinity (up to $25 \%(w / v)$ ) showed an antimicrobial efficacy against human pathogens. The strongest power inhibitory action was observed against Staphylococcus aureus. The molecule responsible of the activity was identified as Bisvertinolone, a compound member of the family Sorbicillinoid [87]. Aspergillus flocculosus PT05-1 and Aspergillus terreus PT06-2, both isolated from sediment of Putian sea saltern of Fujian, China, showed antimicrobial activity against Enterobacter aerogenes, Pseudomonas aeruginosa, and Candida albicans. Strain PT05-1 produces 11 metabolites among which two are new ergosteroids and pyrrole derivative compounds [100], and strain PT06-2 produces the novel compounds: Terrelactone A and Terremides A and B [101]. Other strains of the genus Aspergillus, like A. terreus Tsp22 [101-103], A. flavus, A. gracilis, and A. penicillioids [102] have antibacterial and antioxidant activities in crude extracts but the molecule has not been identified. In the atlas of Wang et al. (2014), 360 fungi were genome-mined cataloguing a total of 307 gene clusters from 30 strains of the phylum Ascomycota. Within this group, strains of the genus Aspergillus: A. nidulans FGSC A4, A. fumigatus, A. niger CBS 513 88, and A. oryzae RIB40 harbor NRPSs, PKSs and hybrids gene clusters [55]. These results confirm that the genus Aspergillus is among the most prolific producers of antimicrobial metabolites. In spite of the prosperous production of compounds from fungi, the active molecules derived from extremely halophilic fungi are still scarce (Table 3). It is highly probable that through genome-driven studies in halophilic fungi, NRPSs and PKSs are substantially present as their peers providing new insights into the fungal biosynthetic pathways. 
Table 3. Halophilic fungi showing antimicrobial activity.

\begin{tabular}{|c|c|c|c|c|c|}
\hline Isolation Source & Species & Antimicrobial Activity & Molecule & Formula & Reference \\
\hline $\begin{array}{l}\text { Abyssal marine sediment. Barents } \\
\text { Sea. Arctic Ocean }\end{array}$ & Aspergillus protuberus MUT 3638 & $\begin{array}{l}\text { S. aureus, } \\
\text { K. pneumoniae, } \\
\text { A. baumanii } \\
\text { and B. metallica }\end{array}$ & Bisvertinolone & $\mathrm{C}_{28} \mathrm{H}_{33} \mathrm{O}_{9}$ & [87] \\
\hline Solar saltern, Phetchaburi, Thailand & $\begin{array}{l}\text { Aspergillus flavus, } \\
\text { Aspergillus gracilis, } \\
\text { and Aspergillus penicillioids }\end{array}$ & $\begin{array}{l}\text { Antibacterial and } \\
\text { antioxidant }\end{array}$ & Crude extracellular compounds & NR & [102] \\
\hline \multirow{2}{*}{ Putian saltern of Fujian, China } & \multirow{2}{*}{ Aspergillus flocculosus PT05-1 } & \multirow{2}{*}{$\begin{array}{l}\text { E. aerogenes, } \\
\text { P. aeruginosa, } \\
\text { and C. albicans }\end{array}$} & $\begin{array}{l}\text { Ergosteroids: } \\
\text { (22R,23S)-epoxy-3b,11a,14b,16b-tetrahydr- } \\
\text { oxyergosta-5,7-dien-12-one }\end{array}$ & $\mathrm{C}_{28} \mathrm{H}_{42} \mathrm{O}_{6}$ & \multirow{2}{*}{ [100] } \\
\hline & & & $\begin{array}{l}\text { Pyrrole derivates: } \\
6 \text {-(1H-pyrrol-2-yl) } \\
\text { hexa-1,3,5-trienyl-4-methoxy-2H-pyran-2-one }\end{array}$ & $\mathrm{C}_{16} \mathrm{H}_{15} \mathrm{NO}_{3}$ & \\
\hline \multirow{3}{*}{ Putian saltern of Fujian, China } & \multirow{3}{*}{ Aspergillus terreus PT06-2 } & \multirow{3}{*}{$\begin{array}{l}\text { E. aerogenes, } \\
\text { P. aeruginosa, } \\
\text { and C. albicans }\end{array}$} & Terremide A & $\mathrm{C}_{21} \mathrm{H}_{17} \mathrm{~N}_{3} \mathrm{O}_{5}$ & \multirow{3}{*}{ [101] } \\
\hline & & & Terremide B & $\mathrm{C}_{21} \mathrm{H}_{15} \mathrm{~N}_{3} \mathrm{O}_{4}$ & \\
\hline & & & Terrelactone A & $\mathrm{C}_{24} \mathrm{H}_{26} \mathrm{O}_{8}$ & \\
\hline Semiarid saltpans in Botwana & Aspergillus terreus Tsp22 & $\begin{array}{l}\text { B. megaterium } \\
\text { and S. aureus }\end{array}$ & Crude extracellular compounds & NR & [103] \\
\hline
\end{tabular}

(E.): E. aerogenes. Escherchia (E.): E. coli. Haemophilus (H.): H. influenzae. Klebsiella (K.): K. pneumonia. Pseudomonas (P.): P. aeruginosa. Staphylococcus (S.): S. aureus. 


\section{Anticancer Compounds}

Natural products are relevant anticancer drugs, which are also called bioactive molecules, produced by organisms. Although, earlier and the well-established anticancer natural products have been obtained from plant cells originally, microorganisms are an excellent alternative, due to the diversity of the microbial world, their easy manipulation, and they can be screened physiologically to discover new natural products with antitumor activity. Although bacterial cells have different communication methods with tumor cells other than metabolites experimentally, bacterial metabolites have been considered the most conventional way against cancer cells viability. Today, more attention is focused on extremophiles as a new source of novel biomolecules [104,105]. Among extremophiles, halophilic and halotolerant microorganisms, which inhabit hypersaline environments, are considered as reliable sources of antitumor metabolites with fewer side effects. In recent years, several studies have been focused on the importance of metabolites from halophilic microorganisms on cancer treatment. The halophilic bacteria, archaea, and fungi involved on the production of anti-cancer biomolecules are summarized in Table 4.

\subsection{Bacteria}

Since the last two decades, halophilic bacteria have attracted the interests of researchers due to their adaptability to a wide range of salinities. Some studies have been carried out to determine the role of halophilic bacteria in cancer treatment. In one of these studies, Chen et al. (2010) assayed fourteen crude extracts from 45 halophilic bacterial strains and showed cytotoxic activity against human liver cancer cell line Bel 7402 with a half maximal inhibitory concentration $\left(\mathrm{IC}_{50}\right)$ of $500 \mu \mathrm{g} / \mathrm{mL}$ and five of them showed remarkable activities with IC50 lower than $40 \mu \mathrm{g} / \mathrm{mL}$ [106]. The antineoplastic antibiotic known as tubercidin, was isolated from the halophilic actinobacterium Actinopolyspora erythraea YIM 90600, this compound exhibited the capability to stabilize the tumor suppressor Programmed Cell Death Protein 4 (Pdcd4), which is known to antagonize critical events in oncogenic pathways. Tubercidin, significantly inhibited proteasomal degradation of a model Pdcd4-luciferase fusion protein, with an $\mathrm{IC}_{50}$ of $0.88 \pm 0.09 \mu \mathrm{M}$, unveiling a novel biological activity for this well-studied natural product [107].

In two studies on different extracts of halophilic and halotolerant bacteria isolated from brine-seawater interface of the Red Sea, Sagar et al. (2013) tested the cytotoxic and apoptotic activity of their extracts against three human cancer cell lines, including HeLa (cervical carcinoma), MCF-7 (breast adenocarcinoma) and DU145 (prostate carcinoma). In one of their studies, a total of 20 lipophilic (chloroform) and hydrophilic (70\% ethanol) extracts from twelve different strains were assessed. Among these, twelve extracts were found to be very active after $24 \mathrm{~h}$ of treatment, which were further evaluated for their cytotoxic and apoptotic effects at $48 \mathrm{~h}$. The extracts from the isolates Halomonas sp. P1-37B, Halomonas sp. P3-37A, and Sulfitobacter sp. P1-17B were found to be the most potent against tested cancer cell lines [108]. In the other study, ethyl acetate extracts of 24 strains were assayed and the results showed that most extracts were cytotoxic against one or more cancer cell lines. Out of the thirteen most active microbial extracts, six extracts induced significantly higher apoptosis $(>70 \%)$ in cancer cells. Molecular studies revealed that extracts from Chromohalobacter salexigens strains P3-86A and P3-86B followed the sequence of events of apoptotic pathway involving matrix metalloproteinases (MMP) disruption, Caspase-3/7 activity, Caspase-8 cleavage, polymeric adenosine diphosphate ribose polymerase 1 (PARP-1) cleavage, and phosphatidylserine exposure, whereas the extracts from another Chromohalobacter salexigens strain K30 induced Caspase-9 mediated apoptosis. The extracts from Halomonas meridiana strain P3-37B and Idiomarina loihiensis strain P3-37C were unable to induce any change in MMP in HeLa cancer cells and thus suggested a mitochondria-independent apoptosis induction. However, further detection of a PARP-1 cleavage product and the observed changes in Caspase- 8 and Caspase- 9 suggested the involvement of caspase-mediated apoptotic pathways [109]. An ethyl acetate extract from Streptomyces sp. WH26 showed significant cellular toxicity. Two new compounds, 8-O-methyltetrangulol and naphthomycin A, were isolated from this extract via silica gel column chromatography and high-pressure liquid chromatography (HPLC). These 
two compounds showed potent cytotoxic activity against several human cancer cell lines including A549, HeLa, BEL-7402, and HT-29 [110]. Novel anticancer molecules, Salternamide A-D, were isolated from a halophilic Streptomyces sp. isolated from a saltern on Shinui Island, in the Republic of Korea, and exhibited an extensive viability reduction in several cancer cell lines [111]. Among these molecules, Salternamide A inhibited the hypoxia-induced accumulation of HIF-1 $\alpha$ in several cancer cell lines and suppressed the HIF-1 $\alpha$ by downregulation of its upstream signaling pathways such as PI3K/Akt/mTOR, p42/p44 MAPK, and STAT3. Moreover, in human colorectal cancer cell lines, salternamide A caused cell death by arresting the cells in the G2/M phase and lead to apoptosis [112]. A halophilic bacterium, Vibrio sp. strain A1SM3-36-8, isolated from Manaure solar saltern in Colombia, showed a high potential to inhibit methicillin-resistant Staphylococcus aureus and causing a slight inhibition of lung cancer cell lines [51]. In another study, among nine moderately halophilic bacteria isolated from saline environments of Iran, the supernatant of four strains showed ability to reduce the viability of HUVEC cancer cell line while one of these supernatants induced the proliferation of adipose-derived mesenchymal stem cells [113]. The actinobacterium Nocardiopsis lucentensis DSM 44048 isolated from Salt marsh soil in Alicante, Spain produces a new benzoxazole derivatives, Nocarbenzoxazole G. The compound showed cytotoxic activity against liver carcinoma cells (HepG2) and HeLa cancer cells with IC50 values of 3 and $1 \mu \mathrm{M}$, respectively [114]. A halotolerant Bacillus sp. KCB14S006, which was isolated from a saltern, produced three new lipopeptides with cytotoxic activity. These new lipopeptides lead to a $\sim 30 \%$ decrease in the viability of HeLa and src(ts)-NRK cells [115]. In another study, the methanolic extracts of Bacillus sp. VITPS14 and Bacillus sp. VITPS16 showed cytotoxicity against HeLa cancer cell line but not against A549 cells. These halophilic strains were isolated from soil samples of Marakkanam saltern and Pichavaram mangrove forest, India, respectively. Another halophilic strain, Bacillus sp. VITPS7, isolated from this area showed significant antioxidant activity. The presence of $\beta$-carotene and flavonoids was confirmed in these extracts [116]. In another study, twenty-four novel halophilic bacteria isolated from the surrounding of active volcanic Barren Island Andaman and the Nicobar Islands in India were examined for their cytotoxic activity against MDA-MB-231 breast cancer cell line. About $65 \%$ of these bacterial strains decreased the viability of this cell line to $50 \%$ or lower [117]. Metabolites from Piscibacillus sp. C12A1 isolated from Sambhar Lake, India, decreased the viability of MDA-MB-231 breast cancer cell line with downregulation of Bcl-xL and CDK-2 expression. Furthermore, cell migration and colony formation of the cells were inhibited in the presence of these metabolites [118].

Biosurfactants produced by microorganisms are active molecules that create an amphipathic surface containing hydrophilic and hydrophobic moieties. In recent years, these biomolecules were also found to possess several interesting properties of therapeutic and biomedical importance. Biosurfactants from the halophilic bacteria Bacillus sp. BS3 and Halomonas sp. BS4 had the ability to reduce the viability of mammary epithelial carcinoma cells to $24.8 \%$ and to 46.8 significantly $(p<0.05)$ at 0.25 $\mu \mathrm{g} / \mathrm{mL}$ and $2.5 \mu \mathrm{g} / \mathrm{mL}$ concentrations, respectively [53,119].

Extracellular polymeric substances (EPS) have recently been attracting considerable attention because of their potential applications in many fields, including biomedicine. EPSs are heterogeneous polymers that contain a wide range of homo- or hetero-carbohydrates as well as organic and inorganic substituents. EPSs produced by both halophilic bacteria and archaea showed remarkable anticancer activity. Also, these polysaccharide polymers have been introduced as important agents for developing nanocarrier systems for anti-cancer drugs. For example, in 2011, Ruiz-Ruiz et al. showed that at a concentration of $500 \mu \mathrm{g} / \mathrm{mL}$, the over sulfated exopolysaccharide of the halophilic bacterium Halomonas stenophila strain B100 completely blocked the proliferation of the human T leukemia cells (Jurkat cells) in a dose-response manner. Also, they revealed the positive effect of sulfate groups in viability reduction of Jurkat cells [120]. Moreover, in another study, the anti-cancer activity of the polysaccharide levan and its aldehyde-activated derivatives was reported. This polysaccharide was isolated from Halomonas smyrnensis AAD6 and its anticancer activity against human cancer cell lines such as lung (A549), liver (HepG2/C3A), gastric (AGS), and breast (MCF-7) cancer cells (Table 4) has been investigated. In this 
study, all evaluated cells were treated with levan samples at a broad concentration ranging from 10 to $1000 \mu \mathrm{g} / \mathrm{mL}$. All samples were found to display growth inhibition against cancer cell lines at the highest dose $(1000 \mu \mathrm{g} / \mathrm{mL})$. Unmodified levan showed higher anti-cancer effect against AGS cells against other cancer cell lines. Aldehyde-activated levan showed higher anti-tumor activity than unmodified levan against all cancer cell lines. Oxidized levan samples showed higher anticancer activity against A549 and HepG2/C3A cells. By increasing the oxidation degree, the anti-cancer activity also increased. Therefore, it was clearly demonstrated that the introduction of the chemically modified group, aldehydes, into the linear levan molecule could significantly enhance the antitumor activity of levan polysaccharide [121].

Recent preclinical and medicinal studies have shown an inverse relationship between dietary uptake of carotenoids and cancer occurrence. It was reported that the extracted carotenoid from the halotolerant bacterium Kocuria sp. QWT-12, isolated from industrial tannery wastewater in Qom, in Iran, had the ability to reduce the viability of human breast cancer cell lines MCF-7, MDA-MB-468, and MDA-MB-231 with an IC50 of 1, 4, and $8 \mathrm{mg} / \mathrm{mL}$, respectively. Also, this carotenoid decreased the viability of human lung cancer cell line A549, with IC50 of $4 \mathrm{mg} / \mathrm{mL}$. This carotenoid did not reduce the viability of normal fibroblast cell line at these concentrations [122].

Among all anticancer enzymes, L-asparaginase and L-glutaminase are enzymes with the ability to inhibit acute lymphoblastic leukemia and other cancer cells. Halophilic and halotolerant bacteria are novel sources of these anticancer enzymes. For example, a screening from 85 halophilic strains from the hypersaline Urmia Lake in Iran revealed that $16(19 \%)$ and three strains (3.5\%) showed L-asparaginase and L-glutaminase activity, respectively. It was shown that L-asparaginase was produced mainly by strains belonging to the genus Bacillus, while L-glutaminase was produced mainly by strains of the genus Salicola [27]. In another study, it was reported that from 110 halophilic strains isolated from different saline environments of Iran, a total of 29, four, and two strains produced anticancer enzymes including L-asparaginase, L-glutaminase, and L-arginase, respectively. These strains belonged to the genera Bacillus, Dietzia, Halobacillus, Rhodococcus, Paenibacillus, and Planococcus, as Gram-positive bacteria, and Pseudomonas, Marinobacter, Halomonas, Idiomarina, Vibrio, and Stappia as Gram-negative bacteria [123]. From these strains, the anti-cancer activity of a novel recombinant L-asparaginase enzyme produced by Halomonas elongata strain IBRC M10216 was assayed against human lymphoblastic and myeloid leukemia cell lines, Jurkat and U937 (Table 4). This enzyme enhanced the viability of these cancer cell lines with IC50 values of 2 and $1 \mathrm{U} / \mathrm{mL}$, respectively, but at these concentrations had no effect on the viability of normal HUVEC cell line [124]. 
Table 4. Halophilic bacteria, archaea, and fungi and their relation to cancer treatment.

\begin{tabular}{|c|c|c|c|c|c|c|}
\hline $\begin{array}{l}\text { Anticancer Activity } \\
\text { of: }\end{array}$ & Isolation Source & Halophilic Strain & Cancer Cell Lines & Molecule & Formula & Reference \\
\hline & & & Bacteria & & & \\
\hline \multirow{11}{*}{ Metabolite } & \multirow{3}{*}{$\begin{array}{l}\text { Marakkanam saltern and Pichavaram } \\
\text { mangroveForest in India }\end{array}$} & \multirow{3}{*}{ Bacillus sp. VITPS16 } & \multirow{3}{*}{ Cervical carcinoma } & Squalene & $\mathrm{C}_{30} \mathrm{H}_{50}$ & \multirow{3}{*}{ [116] } \\
\hline & & & & 3-Methyl-2-(2-oxopropyl) furan & $\mathrm{C}_{8} \mathrm{H}_{10} \mathrm{O}_{2}$ & \\
\hline & & & & Methyl hexadeconate & $\mathrm{C}_{17} \mathrm{H}_{34} \mathrm{O}_{2}$ & \\
\hline & \multirow{2}{*}{$\begin{array}{l}\text { Topsoil saltern in Jeungdo, } \\
\text { Jeollanam-do, Republic of Korea }\end{array}$} & \multirow{2}{*}{$\begin{array}{l}\text { Nocardiopsis sp. } \\
\text { HYJ128 }\end{array}$} & \multirow{2}{*}{ Stomach and Leukemia carcinoma } & Borrelidin C & $\mathrm{C}_{28} \mathrm{H}_{43} \mathrm{NO}_{7}$ & \multirow{2}{*}{ [42] } \\
\hline & & & & Borrelidin D & $\mathrm{C}_{28} \mathrm{H}_{43} \mathrm{NO}_{7}$ & \\
\hline & \multirow{4}{*}{ Saltern in Incheon in Korea } & \multirow{4}{*}{$\begin{array}{l}\text { Bacillus sp. } \\
\text { KCB14S006 }\end{array}$} & \multirow{4}{*}{$\begin{array}{l}\text { Cervical carcinoma } \\
\text { Myeloid leukemia }\end{array}$} & Iturin $\mathrm{F}_{1}$ & $\mathrm{C}_{51} \mathrm{H}_{80} \mathrm{~N}_{12} \mathrm{O}_{15} \mathrm{Na}$ & \multirow{4}{*}{ [115] } \\
\hline & & & & Iturin $\mathrm{F}_{2}$ & $\mathrm{C}_{51} \mathrm{H}_{80} \mathrm{~N}_{12} \mathrm{O}_{15} \mathrm{Na}$ & \\
\hline & & & & Iturin $\mathrm{A}_{8}$ & $\mathrm{C}_{51} \mathrm{H}_{80} \mathrm{~N}_{12} \mathrm{O}_{14} \mathrm{Na}$ & \\
\hline & & & & Iturin $\mathrm{A}_{9}$ & $\mathrm{C}_{51} \mathrm{H}_{80} \mathrm{~N}_{12} \mathrm{O}_{14} \mathrm{Na}$ & \\
\hline & A saltern on Shinui Island in Korea & Streptomyces sp. & $\begin{array}{l}\text { Colorectal cancer } \\
\text { Gastric cancer }\end{array}$ & Salternamide A & $\mathrm{C}_{23} \mathrm{H}_{32} \mathrm{ClNO}_{5}$ & [111] \\
\hline & Salt marsh soil, Alicante, Spain & $\begin{array}{l}\text { Nocardiopsis } \\
\text { lucentensis DSM } 44048\end{array}$ & $\begin{array}{l}\text { Liver cancer } \\
\text { Cervical cancer cells }\end{array}$ & Nocarbenzoxazole G & $\mathrm{C}_{15} \mathrm{H}_{13} \mathrm{NO}_{4}$ & [114] \\
\hline - & Brine-seawater interface of the Red Sea & $\begin{array}{l}12 \text { halophilic marine } \\
\text { strains }\end{array}$ & $\begin{array}{l}\text { Breast adenocarcinoma } \\
\text { Cervical carcinoma } \\
\text { Prostate carcinoma }\end{array}$ & Crude extract & NR & [108] \\
\hline - & Deep-sea brine pools of the Red Sea & $\begin{array}{l}24 \text { halophilic marine } \\
\text { strains }\end{array}$ & $\begin{array}{l}\text { Breast adenocarcinoma } \\
\text { Cervical carcinoma } \\
\text { Prostate carcinoma }\end{array}$ & Crude extract & NR & [109] \\
\hline - & \multirow{2}{*}{$\begin{array}{l}\text { Weihai Solar } \\
\text { Saltern in China }\end{array}$} & $\begin{array}{l}\text { Streptomyces sp. } \\
\text { WH26 }\end{array}$ & \multirow{2}{*}{$\begin{array}{l}\text { Lung adenocarcinoma } \\
\text { Liver hepatocellular adenocarcinoma } \\
\text { Cervical carcinoma } \\
\text { Colorectal cancer }\end{array}$} & 8-O-Methyltetrangulol & $\mathrm{C}_{20} \mathrm{H}_{14} \mathrm{O}_{4}$ & \multirow[t]{2}{*}{ [110] } \\
\hline- & & & & Naphthomycin A & $\mathrm{C}_{40} \mathrm{H}_{46} \mathrm{ClNO}_{9}$ & \\
\hline \multirow{4}{*}{ - } & \multirow{3}{*}{$\begin{array}{l}\text { Baicheng salt field, Xingjiang Province, } \\
\text { China }\end{array}$} & \multirow{3}{*}{$\begin{array}{l}\text { Actinopolyspora } \\
\text { erythraea YIM } 90600\end{array}$} & \multirow{3}{*}{$\begin{array}{l}\text { Colorectal cancer } \\
\text { Tumor suppressor Programmed Cell Death Protein } 4 \\
\text { (Pdcd4) }\end{array}$} & Actinopolysporins A & $\mathrm{C}_{15} \mathrm{H}_{28} \mathrm{O}_{4}$ & \multirow{3}{*}{ [107] } \\
\hline & & & & Actinopolysporins B & $\mathrm{C}_{16} \mathrm{H}_{30} \mathrm{O}_{4}$ & \\
\hline & & & & Actinopolysporins $\mathrm{C}$ & $\mathrm{C}_{16} \mathrm{H}_{30} \mathrm{O}_{2}$ & \\
\hline & $\begin{array}{l}\text { Weihai Solar } \\
\text { Saltern in China }\end{array}$ & $\begin{array}{l}45 \text { moderately } \\
\text { halophilic strains }\end{array}$ & Liver hepatocellular adenocarcinoma & Crude extracts & NR & [106] \\
\hline
\end{tabular}


Table 4. Cont

\begin{tabular}{|c|c|c|c|c|c|c|}
\hline $\begin{array}{l}\text { Anticancer Activity } \\
\text { of: }\end{array}$ & Isolation Source & Halophilic Strain & Cancer Cell Lines & Molecule & Formula & Reference \\
\hline \multirow{3}{*}{$\begin{array}{l}\text { Supernatant } \\
\text { metabolite }\end{array}$} & Sambhar Lake in India & $\begin{array}{l}\text { Piscibacillus sp. } \\
\text { C12A1 }\end{array}$ & Breast adenocarcinoma & Crude extract & NR & [118] \\
\hline & $\begin{array}{l}\text { Brine and sediment of the Manaure } \\
\text { solar saltern in Colombia }\end{array}$ & Vibrio sp. A1SM3-36-8 & Lung adenocarcinoma & 13-cis-docosenamide & $\mathrm{C}_{22} \mathrm{H}_{43} \mathrm{NO}$ & [51] \\
\hline & Different hypersaline lakes in Iran & $\begin{array}{l}9 \text { moderately } \\
\text { halophilic strains }\end{array}$ & Umbilical vein endothelial cancer cell & Crude extract & NR & [113] \\
\hline \multirow{10}{*}{ Biosurfactant } & \multirow{3}{*}{$\begin{array}{l}\text { Thamaraikulam solar salt works in } \\
\text { India }\end{array}$} & \multirow{3}{*}{ Halomonas sp. BS4 } & \multirow{3}{*}{ Mammary epithelial carcinoma } & 1,2-Ethanediamine, $N, N, N^{\prime}, N^{\prime}$-tetra & $\mathrm{C}_{6} \mathrm{H}_{16} \mathrm{~N}_{2}$ & \multirow{3}{*}{ [119] } \\
\hline & & & & 8-Methyl-6-nonenamide & $\mathrm{C}_{10} \mathrm{H}_{19} \mathrm{NO}$ & \\
\hline & & & & 9-Octadecenamide, (Z) & $\mathrm{C}_{18} \mathrm{H}_{35} \mathrm{NO}$ & \\
\hline & \multirow{7}{*}{ Solar salt works in India } & \multirow{7}{*}{ Bacillus sp. BS3 } & \multirow{7}{*}{ Mammary epithelial carcinoma } & 13-Docosenamide, (Z) & $\mathrm{CH}_{3}\left(\mathrm{CH}_{2}\right)_{7} \mathrm{CH}=\mathrm{CH}\left(\mathrm{CH}_{2}\right)_{11} \mathrm{CONH}_{2}$ & \multirow{7}{*}{ [53] } \\
\hline & & & & Mannosamine & $\mathrm{C}_{6} \mathrm{H}_{13} \mathrm{NO}_{5} \cdot \mathrm{HCl}$ & \\
\hline & & & & 9-Octadecenamide, $(\mathrm{Z})$ & $\mathrm{C}_{18} \mathrm{H}_{35} \mathrm{NO}$ & \\
\hline & & & & 2-Octanol,2-methyl-6-methylene & $\mathrm{C}_{12} \mathrm{H}_{22} \mathrm{O}_{2}$ & \\
\hline & & & & Cylohex-1,4,5-triol-3-one-1-carbo & $\mathrm{C}_{5} \mathrm{H}_{8} \mathrm{FN}_{3}$ & \\
\hline & & & & 2-Butanamine, 2-methyl- & $\mathrm{C}_{5} \mathrm{H}_{13} \mathrm{~N}$ & \\
\hline & & & & $\begin{array}{l}\text { 1,2-Ethanediamine, } \\
N, N, N^{\prime}, N^{\prime} \text {-tetramethyl- }\end{array}$ & $\mathrm{C}_{6} \mathrm{H}_{16} \mathrm{~N}_{2}$ & \\
\hline \multirow[t]{2}{*}{ Exopolysaccharide } & Çamalti saltern area in Turkey & $\begin{array}{l}\text { Halomonas smyrnensis } \\
\text { strain AAD6 }\end{array}$ & $\begin{array}{l}\text { Breast adenocarcinoma } \\
\text { Lung adenocarcinoma } \\
\text { Liver hepatocellular adenocarcinoma } \\
\text { Gastric adenocarcinoma }\end{array}$ & Levan & $\mathrm{C}_{18} \mathrm{H}_{32} \mathrm{O}_{16}$ & [121] \\
\hline & Sabinar saline wetland in Spain & $\begin{array}{l}\text { Halomonas stenophila } \\
\text { strain B100 }\end{array}$ & Lymphoblastic leukemia & $\begin{array}{l}\text { Single acidic exopolysaccharide } \\
\text { with glucose, mannose } \\
\text { and galactose }\end{array}$ & NR & [120] \\
\hline Carotenoid & Industrial tannery wastewater in Iran & Kocuria sp. MA-2 & Prostate carcinoma & Neurosporene & $\mathrm{C}_{40} \mathrm{H}_{58}$ & [122] \\
\hline Enzyme & Hypersaline soil in Iran & $\begin{array}{l}\text { Halomonas elongata } \\
\text { IBRC-M } 10216\end{array}$ & $\begin{array}{l}\text { Lymphoblastic leukemia } \\
\text { Myeloid leukemia }\end{array}$ & L-asparaginase & $\mathrm{C}_{1377} \mathrm{H}_{2208} \mathrm{~N}_{382} \mathrm{O}_{442517}$ & [124] \\
\hline
\end{tabular}


Table 4. Cont

\begin{tabular}{|c|c|c|c|c|c|c|}
\hline $\begin{array}{l}\text { Anticancer Activity } \\
\text { of: }\end{array}$ & Isolation Source & Halophilic Strain & Cancer Cell Lines & Molecule & Formula & Reference \\
\hline \multicolumn{7}{|l|}{ Archaea } \\
\hline $\begin{array}{l}\text { Supernatant } \\
\text { metabolite }\end{array}$ & Aran Bidgol hypersaline lake in Iran & $\begin{array}{l}\text { Halobacterium } \\
\text { salinarum IBRC-M } \\
10715\end{array}$ & Prostate carcinoma & Crude extract & NR & [105] \\
\hline Exopolysaccharide & Urmia Lake in Iran & $\begin{array}{l}\text { Halorubrum sp. } \\
\text { TBZ112 }\end{array}$ & Gastric adenocarcinoma & $\begin{array}{l}\text { Monosaccharide composition } \\
\text { mainly composed of mannose, } \\
\text { glucosamine, galacturonic acid, } \\
\text { arabinose, and glucuronic acid }\end{array}$ & NR & [125] \\
\hline \multirow[t]{2}{*}{ Carotenoid } & Marine solar saltern in eastern China & $\begin{array}{l}\text { Halogeometricum limi } \\
\text { strain RO1-6 } \\
\text { Haloplanus vescus } \\
\text { strain RO5-8 }\end{array}$ & Liver hepatocellular adenocarcinoma & Bacterioruberin & $\mathrm{C}_{50} \mathrm{H}_{76} \mathrm{O}_{4}$ & [127] \\
\hline & Tunisian solar saltern & $\begin{array}{l}\text { Halobacterium } \\
\text { halobium }\end{array}$ & Liver hepatocellular adenocarcinoma & Bacterioruberin & $\mathrm{C}_{50} \mathrm{H}_{76} \mathrm{O}_{4}$ & [126] \\
\hline \multicolumn{7}{|l|}{ Fungi } \\
\hline \multirow{3}{*}{ Metabolite } & \multirow{3}{*}{$\begin{array}{l}\text { Weihai Solar } \\
\text { Saltern in China }\end{array}$} & \multirow{3}{*}{ Aspergillus sp. $\mathrm{F} 1$} & Lung adenocarcinoma & Cytochalasin E & $\mathrm{C}_{28} \mathrm{H}_{33} \mathrm{NO}_{7}$ & \multirow{3}{*}{ [128] } \\
\hline & & & Cervical carcinoma & Ergosterol & $\mathrm{C}_{28} \mathrm{H}_{44} \mathrm{O}$ & \\
\hline & & & Colorectal cancer & Rosellichalasin & $\mathrm{C}_{28} \mathrm{H}_{33} \mathrm{NO}_{5}$ & \\
\hline
\end{tabular}




\subsection{Archaea}

Although most studies in this field have been focused on halophilic bacteria, some studies investigated the potentials of haloarchaea. In one of these studies, among nine haloarchaeal strains isolated from Aran-Bidgol Salt Lake, in Iran, supernatant metabolites from Halobacterium salinarum IBRC M10715 had the most potent cytotoxic effect on prostate cancer cell lines (DU145 and PC3, IC50 $=0.5 \mathrm{mg} / \mathrm{mL}$ ) without any effects on normal fibroblast cells (HFF-5). Moreover, the selective metabolite significantly increased both early and late apoptosis (about $11 \%$ and $9 \%$, respectively) in the androgen-dependent PC3 cell line and reduced sphere formation ability of both cancer cell lines with down-regulation of SOX2 gene expression. Furthermore, prostate cancer cell tumors developed in nude mice significantly shrank post intratumor injection of the metabolite from Halobacterium salinarum IBRC M10715 [105]. Halorubrum sp. TBZ112 is a haloarchaeal species isolated from the Urmia Lake, Iran. It was reported that this strain could produce EPSs. The isolated EPSs possess a relatively low molecular weight in comparison with those EPSs isolated from other extreme environments (5 vs. $\geq 100 \mathrm{kDa}$, respectively) and the absence of sulfate functional groups in their structure was reported. The anticancer activity of the EPSs from Halorubrum sp. TBZ112 was examined and the results did not show any significant changes in the viability of gastric cancer cells (MKN-45) and normal human dermal fibroblast cells (HDF) at concentrations of 100, 250, 500, and $1000 \mu \mathrm{g} / \mathrm{mL}$ after 24 and $48 \mathrm{~h}$ of treatment. As the existence of sulfate functional groups and the EPSs bioactivities are directly related, the low cytotoxicity potential of the EPSs from Halorubrum sp. TBZ112 was not unexpected [125].

Both in vivo and in vitro studies confirm chemoprevention effects of some carotenoids anticancer activity. Halophilic microorganisms showed great potential toward the production of various carotenoids such as $\beta$-carotene, bacterioruberin, and xanthophylls. In recent years, some investigations were carried out to determine the role of carotenoids or other bioactive molecules produced by halophiles on cancer treatment. The effects of Halobacterium halobium carotenoid extract on the viability of human hepatoma, HepG2, have been analyzed. This haloarchaeal strain was isolated from a Tunisian solar saltern and the results emphasized that increasing concentrations of the carotenoid extract of this halophilic archaeon decreased significantly the viability of the HepG2 cancer cell line [126]. Carotenoids from the haloarchaea Halogeometricum limi strain RO1-6 and Haloplanus vescus strain RO5-8 showed a potent antioxidant activity in comparison with $\beta$-carotene. In addition, these carotenoid extracts inhibited HepG2 cells in vitro, in a dose-dependent manner. Bacterioruberin was the predominant carotenoid extracted from these haloarchaea [127].

\subsection{Fungi}

The biotechnological applications of halophilic fungi are remarkedly less studied in comparison with halophilic bacteria. There is only one study focused on the cytotoxic effect of metabolites from a moderately halophilic fungal strain, Aspergillus sp. F1 [128]. Based on this publication, this strain produced three compounds with anticancer activity including cytochalasin E, ergosterol, and rosellichalasin, and higher salt concentrations increased the production of these compounds. All isolated compounds decreased the viability of A549, Hela, BEL-7402, and RKO human cancer cell lines and the inhibition effect of ergosterol on human colon cancer cell line, RKO, was the most potent cytotoxic report in this study.

Table 4 summarize all the mentioned reports in Section 4, which are related to the anticancer effect of halophilic bacteria, archaea, and fungi isolated from different saline and hypersaline environments in the world.

The following table (Table 5) gathers the most promising new compounds derived from halophilic microorganisms. The minimum inhibitory concentration (MIC) and the half maximal inhibitory concentration $\left(\mathrm{IC}_{50}\right)$ are shown, based on their in vitro bioactivity. The results suggest that these compounds could be candidates for preclinical trials. 
Table 5. Promising new compounds derived from halophilic microorganisms candidates for preclinical trials.

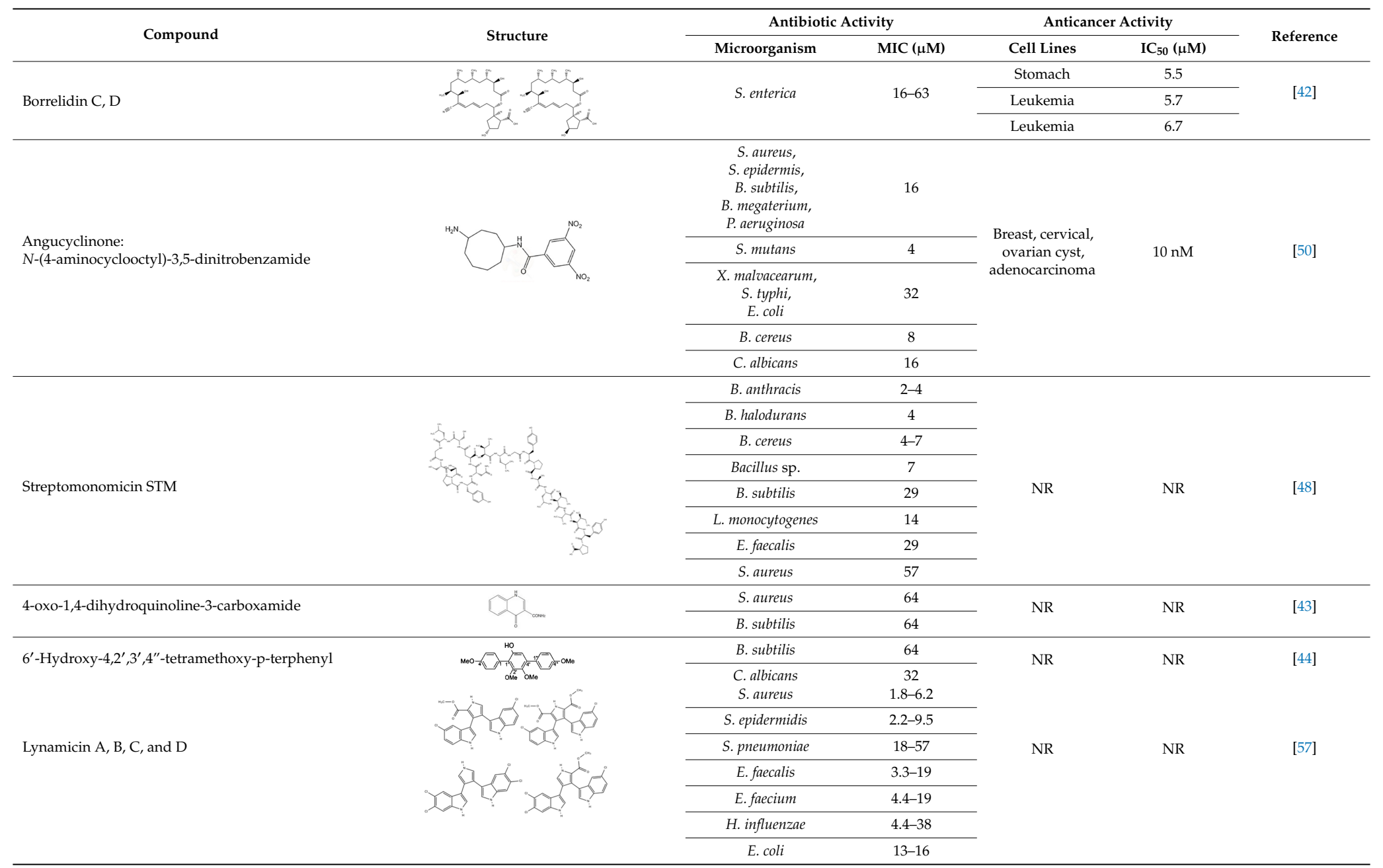


Table 5. Cont.

\begin{tabular}{|c|c|c|c|c|c|c|}
\hline \multirow{2}{*}{ Compound } & \multirow{2}{*}{ Structure } & \multicolumn{2}{|c|}{ Antibiotic Activity } & \multicolumn{2}{|c|}{ Anticancer Activity } & \multirow{2}{*}{ Reference } \\
\hline & & Microorganism & MIC $(\mu \mathrm{M})$ & Cell Lines & $\mathrm{IC}_{50}(\mu \mathrm{M})$ & \\
\hline \multirow{4}{*}{ Essramycin } & & E. coli & 8 & \multirow{4}{*}{ NR } & \multirow{4}{*}{ NR } & \multirow{4}{*}{ [58] } \\
\hline & & P. aeruginosa & 3.5 & & & \\
\hline & & $\begin{array}{l}\text { B. subtilis, } \\
\text { S. aureus }\end{array}$ & 1 & & & \\
\hline & & M. luteus & 1.5 & & & \\
\hline \multirow{3}{*}{$\begin{array}{l}\text { Resistomycin } \\
\text { 1-hydroxy-1-Norresistomycin }\end{array}$} & & E. coli & & & & \multirow{5}{*}[60]{} \\
\hline & & S. aureus & 40 & NR & NR & \\
\hline & & S. viridochromogenes & & & & \\
\hline \multirow[b]{2}{*}{ Resistoflavin methyl ether } & & B. subtilis & 3.1 & \multirow[b]{2}{*}{ NR } & \multirow[b]{2}{*}{ NR } & \\
\hline & $\mathrm{R}=\mathrm{Me}$ & $\begin{array}{c}\text { E. coli, } \\
\text { S. aureus, } \\
\text { C. albicans }\end{array}$ & 10 & & & \\
\hline \multirow{7}{*}{ Lajollamycin } & & MSSA & 4 & \multirow{7}{*}{$\begin{array}{c}\text { Murine } \\
\text { melanoma cell } \\
\text { line B16-F10 }\end{array}$} & \multirow{7}{*}{9.6} & \multirow{7}{*}{ [61] } \\
\hline & & MRSA & 5 & & & \\
\hline & & SPPS & 2 & & & \\
\hline & & PRSP & 1.5 & & & \\
\hline & & VSEF & 14 & & & \\
\hline & & VREF & 20 & & & \\
\hline & & E. coli & 12 & & & \\
\hline
\end{tabular}

Note: Not reported (NR). Microorganisms: Bacillus (B.): B. cereus, B. halodurans, B. megaterium, B. subtilis, B. anthracis. Candida (C.): C. albicans. Enterococcus (E.): E. faecalis, E. faecium, Vancomycin resistant Enterococcus faecium (VREF), Vancomycin sensitive Enterococcus faecalis (VSEF), Vancomycin resistant enterococci (VRE). Escherichia (E.): E. coli. Haemophilus (H.): H. influenzae. Listeria (L.): L. monocytogenes. Micrococcus (M.): M. luteus. Pseudomonas (P.): P. aeruginosa. Salmonella (S.): S. typhi, S. enterica. Staphylococcus (S.): S. aureus, S. epidermidis, S. mutans, Methicillin Sensitive Staphylococcus aureus (MSSA), Methicillin-resistant Staphylococcus aureus (MRSA). Streptococcus (S.): S. pneumoniae, Penicillin resistant Streptococcus pneumoniae (PRSP), Penicillin sensitive Streptococcus pneumoniae (SPPS). Streptomyces (S.): S. viridochromogenes. Xanthomonas (X.): X. malvacearum. 


\section{Future Perspectives}

As the prevalence of antimicrobial resistance increases, researchers are developing new technologies and strategies to find alternatives that reduce the morbidity and mortality caused by the MDR bacteria. Categorizing the need for obtaining new molecules, the most requested by the public health are antimicrobial and anticancer compounds according to the data annually reported by the World Health Organization (WHO). The current and future of natural product discovery is the application of a combination of multi-omics approaches. Depending on the phase of the study, it is foreseen genomics, metagenomics, transcriptomics, proteomics, and metabolomics to reveal the biosynthetic capabilities of a single microorganism or microbial communities in hypersaline environments.

The discovery of novel lead compounds requires more that in silico predicted genes and large promising data. The current problem with massive approaches is precisely the lack of concrete results traduced in novel lead compound derived of "meta-omics" studies. The heterologous expression of biosynthetic genes is the bottleneck since in several cases the recombinant product and its expression is totally different from what was expected. However, it is important to emphasize that the cultivation of hidden and uncultivable microbiota is improving with the assessment of metagenomic studies $[129,130]$.

Genome mining has been implemented as a mandatory tool widely used to characterize the genetic basis of secondary metabolite biosynthesis based on the features of secondary metabolites organized as biosynthetic gene clusters (BGCs), especially the profile of gene encoding key signature enzymes [131-133]. The application of Next Generation Sequencing (NGS) allows the study of microbial diversity every day more accessible and affordable that allows the prediction of cryptic metabolic pathways and genes involved in the activity. The genome-guided discovery relies on sophisticated methods for identification of knew gene families related clusters. The accurate prediction and analysis of relevant genes for secondary metabolite biosynthetic pathways in microbes is performed through the tool based on the Antibiotics and Secondary Metabolites Analysis Shell (antiSMASH) [134].

Due to the high rate of rediscovery of known compounds, the dereplication is an essential approach that allows the identification of duplicate molecules. Dereplication is relying on finding a matching of mass spectra with those present in the mass spectrometry data repository. The development of new computational tools like the algorithm searching spectral, DEREPLICATOR+ is helping to identifying in one order of magnitude peptidic natural products (PNPs) that include nonribosomal peptides (NRPs), and ribosomally synthesized and post-translationally modified peptides (RiPPs). The matching is extended to the identification of polyketides, terpenes, benzenoids, alkaloids, flavonoids, and other classes of natural products. One of the utilities of DEREPLICATOR+ is the enabling of cross-validation of genome-mining and peptidogenomics/glycogenomics results [135].

Several laboratories working in microbial bioprospecting keep their private collection once the antimicrobial, anticancer, antifungal, etc. activity is detected. In many cases, these positive isolates derived from primary screenings are not further studied by genome sequencing and dereplication. A common issue is the obtaining of the purified active compound under laboratory conditions with limited facilities and handling large data with a proper analysis. Moreover, it is important to consider the dereplication costs and time-consuming interpreting. The mentioned facts delay the biodiscovery attempts and constitute the reasonable causing of keeping a stored library of potential compounds. The projection of drug discovery product research is the simplification and accessibility to all these tools faster and with less effort. The power of genome mining in studying natural product biosynthesis by showing the widespread distribution of NRPS/PKS gene clusters and by the elicitation of previously unidentified pathways has been demonstrated. It is clear that coupling genome mining and dereplication will accelerate the biodiscovery at initial steps. The integration and linking of computational approaches are certainly the future of natural product research.

In this review, we have focused in all anticancer molecules reported from halophilic microorganisms. According to the cellular lines used, the focus of primary screenings is addressed to the leading cancer types that affect the global population. However, it is important that further screenings should include cellular lines with intrinsic chemoresistance, like sarcoma and glioblastoma, 
characterized by aggressive overproliferation. The future of novel anticancer agents seems to be a combination of high-throughput screening assessed by predictive biomarkers.

Author Contributions: A.V. and P.C. designed the review article. P.C., M.A.A., and A.V. prepared and edited the manuscript. P.C. and M.A.A. prepared the tables. All authors revised and contributed to the preparation of the manuscript. All authors have read and agreed to the published version of the manuscript.

Funding: This study was supported by the Italian Foundation with the South (Fondazione CON IL SUD) project 2018-PDR-00533 (to P.C.), the Spanish Ministry of Economy and Competitiveness (MINECO) through project CGL2017-83385-P, which included European (FEDER) funds, and Junta de Andalucía (Spain) (to A.V.), and the Iranian National Science Foundation (INSF) (to M.A.A.).

Conflicts of Interest: The authors declare that there are no conflicts of interest.

\section{References}

1. Oren, A. Microbial life at high salt concentrations: Phylogenetic and metabolic diversity. Saline Syst. 2008, 4, 2. [CrossRef]

2. Kushner, D.J. Life in high salt and solute concentrations: Halophilic bacteria. In Microbial Life in Extreme Environments; Kushner, D.J., Ed.; Academic Press: London, UK, 1978; p. 318.

3. Kushner, D.; Kamekura, M. Physiology of halophilic eubacteria. In Halophilic Bacteria; Rodriguez-Valera, F., Ed.; CRC Press: Boca Raton, FL, USA, 1988; Volume 1, pp. 109-138.

4. Rodriguez-Valera, F.; Ruiz-Berraquero, F.; Ramos-Cormenzana, A. Characteristics of the heterotrophic bacterial populations in hypersaline environments of different salt concentrations. Microb. Ecol. 1981, 7, 235-243. [CrossRef] [PubMed]

5. Seckbach, J.; Oren, A.; Stan-Lotter, H. (Eds.) Polyextremophiles: Life Under Multiple Forms of Stress; Springer: Heidelberg, Germany, 2013.

6. Bowers, K.J.; Mesbah, N.M.; Wiegel, J. Biodiversity of poly-extremophilic bacteria: Does combining the extremes of high salt, alkaline $\mathrm{pH}$ and elevated temperature approach a physico-chemical boundary for life? Saline Syst. 2009, 5, 9. [CrossRef] [PubMed]

7. Mesbah, N.M.; Wiegel, J. Life under multiple extreme conditions: Diversity and physiology of the halophilic alkalithermophiles. Appl. Environ. Microbiol. 2012, 78, 4074-4082. [CrossRef] [PubMed]

8. Ventosa, A.; Nieto, J.J.; Oren, A. Biology of moderately halophilic aerobic bacteria. Microbiol. Mol. Biol. Rev. 1998, 62, 504-544.

9. Bremer, E.; Krämer, R. Responses of microorganisms to osmotic stress. Annu. Rev. Microbiol. 2019, 73, 313-334. [CrossRef]

10. De la Haba, R.R.; Sánchez-Porro, C.; Marquez, M.C.; Ventosa, A. Taxonomy of halophiles. In Extremophiles Handbook; Horikoshi, K., Ed.; Springer Japan: Tokyo, Japan, 2011; pp. 255-308.

11. Andrei, A.-Ş.; Banciu, H.L.; Oren, A. Living with salt: Metabolic and phylogenetic diversity of archaea inhabiting saline ecosystems. FEMS Microbiol. Lett. 2012, 330, 1-9. [CrossRef]

12. Ventosa, A.; Oren, A.; Ma, Y. (Eds.) Halophiles and Hypersaline Environments; Springer: Berlin/Heidelberg, Germany, 2011.

13. Akpolat, C.; Ventosa, A.; Birbir, M.; Sánchez-Porro, C.; Caglayan, P. Molecular identification of moderately halophilic bacteria and extremely halophilic archaea isolated from salted sheep skins containing red and yellow discolorations. J. Am. Leather Chem. Assoc. 2015, 110, 211-220.

14. Ventosa, A. Unusual micro-organisms from unusual habitats: Hypersaline environments. In Prokaryotic Diversity; Logan, N.A., Lappin-Scott, H.M., Oyston, P.C.F., Eds.; Cambridge University Press: Cambridge, UK, 2006; pp. 223-254.

15. Ventosa, A.; Fernández, A.B.; León, M.J.; Sánchez-Porro, C.; Rodriguez-Valera, F. The Santa Pola saltern as a model for studying the microbiota of hypersaline environments. Extremophiles 2014, 18, 811-824. [CrossRef]

16. Ventosa, A.; de la Haba, R.R.; Sánchez-Porro, C.; Papke, R.T. Microbial diversity of hypersaline environments: A metagenomic approach. Curr. Opin. Microbiol. 2015, 25, 80-87. [CrossRef]

17. Samylina, O.S.; Namsaraev, Z.B.; Grouzdev, D.S.; Slobodova, N.V.; Zelenev, V.V.; Borisenko, G.V.; Sorokin, D.Y. The patterns of nitrogen fixation in haloalkaliphilic phototrophic communities of Kulunda Steppe soda lakes (Altai, Russia). FEMS Microbiol. Ecol. 2019, 95, fiz174. [CrossRef] [PubMed] 
18. Naghoni, A.; Emtiazi, G.; Amoozegar, M.A.; Cretoiu, M.S.; Stal, L.J.; Etemadifar, Z.; Shahzadeh Fazeli, S.A.; Bolhuis, H. Microbial diversity in the hypersaline Lake Meyghan, Iran. Sci. Rep. 2017, 7, 11522. [CrossRef] [PubMed]

19. Amoozegar, M.A.; Siroosi, M.; Atashgahi, S.; Smidt, H.; Ventosa, A. Systematics of haloarchaea and biotechnological potential of their hydrolytic enzymes. Microbiology 2017, 163, 623-645. [CrossRef] [PubMed]

20. Oren, A.; Rodriguez-Valera, F. The contribution of halophilic bacteria to the red coloration of saltern crystallizer ponds. FEMS Microbiol. Ecol. 2001, 36, 123-130. [CrossRef]

21. Charlesworth, J.C.; Burns, B.P. Untapped resources: Biotechnological potential of peptides and secondary metabolites in archaea. Archaea 2015, 2015, 1-7. [CrossRef]

22. Chen, Y.-H.; Lu, C.-W.; Shyu, Y.-T.; Lin, S.-S. Revealing the saline adaptation strategies of the halophilic bacterium Halomonas beimenensis through high-throughput omics and transposon mutagenesis approaches. Sci. Rep. 2017, 7, 13037. [CrossRef]

23. Das, S.; Dash, H.R. (Eds.) Microbial Diversity in the Genomic Era; Academic Press: Cambridge, MA, USA; Elsevier: Amsterdam, The Netherlands, 2018.

24. Vavourakis, C.D.; Mehrshad, M.; Balkema, C.; van Hall, R.; Andrei, A.-Ş.; Ghai, R.; Sorokin, D.Y.; Muyzer, G. Metagenomes and metatranscriptomes shed new light on the microbial-mediated sulfur cycle in a Siberian soda lake. BMC Biol. 2019, 17, 69. [CrossRef]

25. DasSarma, P.; Coker, J.A.; Huse, V.; DasSarma, S. Halophiles, industrial applications. In Encyclopedia of Industrial Biotechnology; American Cancer Society: Atlanta, GA, USA, 2010; pp. 1-43.

26. Yin, J.; Chen, J.-C.; Wu, Q.; Chen, G.-Q. Halophiles, coming stars for industrial biotechnology. Biotechnol. Adv. 2015, 33, 1433-1442. [CrossRef]

27. Shirazian, P.; Asad, S.; Amoozegar, M.A. The potential of halophilic and halotolerant bacteria for the production of antineoplastic enzymes: L-asparaginase and L-glutaminase. EXCLI J. 2016, 15, 268-279.

28. Kiadehi, M.S.H.; Amoozegar, M.A.; Asad, S.; Siroosi, M. Exploring the potential of halophilic archaea for the decolorization of azo dyes. Water Sci. Technol. 2018, 77, 1602-1611. [CrossRef]

29. Giani, M.; Garbayo, I.; Vílchez, C.; Martínez-Espinosa, R.M. Haloarchaeal carotenoids: Healthy novel compounds from extreme environments. Mar. Drugs 2019, 17, 524. [CrossRef] [PubMed]

30. Amoozegar, M.A.; Safarpour, A.; Noghabi, K.A.; Bakhtiary, T.; Ventosa, A. Halophiles and their vast potential in biofuel production. Front. Microbiol. 2019, 10, 1895. [CrossRef] [PubMed]

31. Jin, M.; Gai, Y.; Guo, X.; Hou, Y.; Zeng, R. Properties and applications of extremozymes from deep-sea extremophilic microorganisms: A mini review. Mar. Drugs 2019, 17, 656. [CrossRef] [PubMed]

32. Tseng, W.-P.; Chen, Y.-C.; Chen, S.-Y.; Chen, S.-Y.; Chang, S.-C. Risk for subsequent infection and mortality after hospitalization among patients with multidrug-resistant Gram-negative bacteria colonization or infection. Antimicrob. Resist. Infect. Control 2018, 7, 93. [CrossRef] [PubMed]

33. Peters, L.; Olson, L.; Khu, D.T.K.; Linnros, S.; Le, N.K.; Hanberger, H.; Hoang, N.T.B.; Tran, D.M.; Larsson, M. Multiple antibiotic resistance as a risk factor for mortality and prolonged hospital stay: A cohort study among neonatal intensive care patients with hospital-acquired infections caused by gram-negative bacteria in Vietnam. PLoS ONE 2019, 14, e0215666. [CrossRef]

34. Cassini, A.; Högberg, L.D.; Plachouras, D.; Quattrocchi, A.; Hoxha, A.; Simonsen, G.S.; Colomb-Cotinat, M.; Kretzschmar, M.E.; Devleesschauwer, B.; Cecchini, M.; et al. Attributable deaths and disability-adjusted life-years caused by infections with antibiotic-resistant bacteria in the EU and the European Economic Area in 2015: A population-level modelling analysis. Lancet Infect. Dis. 2019, 19, 56-66. [CrossRef]

35. Rodriguez-Valera, F.; Juez, G.; Kushner, D.J. Halocins: Salt-dependent bacteriocins produced by extremely halophilic rods. Can. J. Microbiol. 1982, 28, 151-154. [CrossRef]

36. Gohel, S.D.; Sharma, A.K.; Dangar, K.G.; Thakrar, F.J.; Singh, S.P. Antimicrobial and biocatalytic potential of haloalkaliphilic actinobacteria. In Halophiles; Maheshwari, D.K., Saraf, M., Eds.; Springer: Heidelberg, Germany, 2015; Volume 6, pp. 29-55.

37. Ventosa, A.; Mellado, E.; Sanchez-Porro, C.; Marquez, M.C. Halophilic and halotolerant microorganisms from soils. In Microbiology of Extreme Soils; Dion, P., Nautiyal, C.S., Eds.; Springer: Berlin/Heidelberg, Germany, 2008; pp. 87-115.

38. Hamedi, J.; Mohammadipanah, F.; Ventosa, A. Systematic and biotechnological aspects of halophilic and halotolerant actinomycetes. Extremophiles 2013, 17, 1-13. [CrossRef] 
39. Manteca, Á.; Yagüe, P. Streptomyces as a source of antimicrobials: Novel approaches to activate cryptic secondary metabolite pathways. In Antimicrobial, Antibiotic Resistant, Antibiofilm Strategies and Activity Methods; Intechopen: London, UK, 2019; pp. 1-21.

40. Adlin Jenifer, J.S.C.; Michaelbabu, M.; Eswaramoorthy Thirumalaikumar, C.L.; Jeraldin Nisha, S.R.; Uma, G.; Citarasu, T. Antimicrobial potential of haloalkaliphilic Nocardiopsis sp. AJ1 isolated from solar salterns in India. J. Basic Microbiol. 2019, 59, 288-301. [CrossRef]

41. Hadj Rabia-Boukhalfa, Y.; Eveno, Y.; Karama, S.; Selama, O.; Lauga, B.; Duran, R.; Hacène, H.; Eparvier, V. Isolation, purification and chemical characterization of a new angucyclinone compound produced by a new halotolerant Nocardiopsis sp. HR-4 strain. World J. Microbiol. Biotechnol. 2017, 33, 126. [CrossRef]

42. Kim, J.; Shin, D.; Kim, S.-H.; Park, W.; Shin, Y.; Kim, W.K.; Lee, S.K.; Oh, K.-B.; Shin, J.; Oh, D.-C. Borrelidins C-E: New Antibacterial macrolides from a saltern-derived halophilic Nocardiopsis sp. Mar. Drugs 2017, 15, 166. [CrossRef] [PubMed]

43. Tian, S.; Yang, Y.; Liu, K.; Xiong, Z.; Xu, L.; Zhao, L. Antimicrobial metabolites from a novel halophilic actinomycete Nocardiopsis terrae YIM 90022. Nat. Prod. Res. 2014, 28, 344-346. [CrossRef] [PubMed]

44. Tian, S.-Z.; Pu, X.; Luo, G.; Zhao, L.-X.; Xu, L.-H.; Li, W.-J.; Luo, Y. Isolation and characterization of new $p$-terphenyls with antifungal, antibacterial, and antioxidant activities from halophilic actinomycete Nocardiopsis gilva YIM 90087. J. Agric. Food Chem. 2013, 61, 3006-3012. [CrossRef] [PubMed]

45. Gorajana, A.; Vinjamuri, S.; Poluri, E.; Zeeck, A. 1-Hydroxy-1-norresistomycin, a new cytotoxic compound from a marine actinomycete, Streptomyces chibaensis. J. Antibiot. 2005, 8, 526-529. [CrossRef] [PubMed]

46. Maskey, R.P.; Helmke, E.; Laatsch, H. Himalomycin A and B: Isolation and structure elucidation of new fridamycin type antibiotics from a marine Streptomyces isolate. J. Antibiot. 2003, 56, 942-949. [CrossRef] [PubMed]

47. Parthasarathi, S.; Sathya, S.; Bupesh, G.; Samy, R.D.; Mohan, M.R.; Kumar, G.S.; Manikandan, M.; Kim, C.J.; Balakrishnan, K. Isolation and characterization of antimicrobial compound from marine Streptomyces hygroscopicus BDUS 49. World J. Fish Mar. Sci. 2012, 4, 268-277.

48. Metelev, M.; Tietz, J.I.; Melby, J.O.; Blair, P.M.; Zhu, L.; Livnat, I.; Severinov, K.; Mitchell, D.A. Structure, bioactivity, and resistance mechanism of Streptomonomicin, an unusual lasso peptide from an understudied halophilic actinomycete. Chem. Biol. 2015, 22, 241-250. [CrossRef]

49. Frikha Dammak, D.; Zarai, Z.; Najah, S.; Abdennabi, R.; Belbahri, L.; Rateb, M.E.; Mejdoub, H.; Maalej, S. Antagonistic properties of some halophilic thermoactinomycetes isolated from superficial sediment of a solar saltern and production of cyclic antimicrobial peptides by the novel isolate Paludifilum halophilum. BioMed Res. Int. 2017, 2017, 1-13. [CrossRef]

50. Mangamuri, U.K.; Vijayalakshmi, M.; Poda, S.; Manavathi, B.; Chitturi, B.; Yenamandra, V. Isolation and biological evaluation of $\mathrm{N}$-(4-aminocyclooctyl)-3,5-dinitrobenzamide, a new semisynthetic derivative from the mangrove-associated actinomycete Pseudonocardia endophytica VUK-10. 3 Biotech 2016, 6, 158. [CrossRef]

51. Conde-Martínez, N.; Acosta-González, A.; Díaz, L.E.; Tello, E. Use of a mixed culture strategy to isolate halophilic bacteria with antibacterial and cytotoxic activity from the Manaure solar saltern in Colombia. BMC Microbiol. 2017, 17, 230. [CrossRef]

52. Bell, R.; Carmeli, S.; Sar, N. Vibrindole A, a Metabolite of the marine bacterium, Vibrio parahaemolyticus, isolated from the toxic mucus of the boxfish Ostracion cubicus. J. Nat. Prod. 1994, 57, 1587-1590. [CrossRef] [PubMed]

53. Donio, M.; Ronica, S.; Viji, V.T.; Velmurugan, S.; Jenifer, J.A.; Michaelbabu, M.; Citarasu, T. Isolation and characterization of halophilic Bacillus sp. BS3 able to produce pharmacologically important biosurfactants. Asian Pac. J. Trop. Med. 2013, 6, 876-883. [CrossRef]

54. Velmurugan, S.; Raman, K.; Thanga Viji, V.; Donio, M.B.S.; Adlin Jenifer, J.; Babu, M.M.; Citarasu, T. Screening and characterization of antimicrobial secondary metabolites from Halomonas salifodinae MPM-TC and its in vivo antiviral influence on Indian white shrimp Fenneropenaeus indicus against WSSV challenge. J. King Saud Univ. Sci. 2013, 25, 181-190. [CrossRef]

55. Wang, H.; Fewer, D.P.; Holm, L.; Rouhiainen, L.; Sivonen, K. Atlas of nonribosomal peptide and polyketide biosynthetic pathways reveals common occurrence of nonmodular enzymes. Proc. Natl. Acad. Sci. USA 2014, 111, 9259-9264. [CrossRef] 
56. Bose, U.; Hewavitharana, A.; Ng, Y.; Shaw, P.; Fuerst, J.; Hodson, M. LC-MS-based metabolomics study of marine bacterial secondary metabolite and antibiotic production in Salinispora arenicola. Mar. Drugs 2015, 13, 249-266. [CrossRef]

57. McArthur, K.A.; Mitchell, S.S.; Tsueng, G.; Rheingold, A.; White, D.J.; Grodberg, J.; Lam, K.S.; Potts, B.C.M. Lynamicins A-E, chlorinated bisindole pyrrole antibiotics from a novel marine actinomycete. J. Nat. Prod. 2008, 71, 1732-1737. [CrossRef]

58. El-Gendy, M.M.A.; Shaaban, M.; Shaaban, K.A.; El-Bondkly, A.M.; Laatsch, H. Essramycin: A first triazolopyrimidine antibiotic isolated from nature. J. Antibiot. 2008, 61, 149-157. [CrossRef]

59. Hughes, C.C.; Prieto-Davo, A.; Jensen, P.R.; Fenical, W. The Marinopyrroles, antibiotics of an unprecedented structure class from a marine Streptomyces sp. Org. Lett. 2008, 10, 629-631. [CrossRef]

60. Kock, I.; Maskey, R.P.; Biabani, M.A.F.; Helmke, E.; Laatsch, H. 1-Hydroxy-1-norresistomycin and resistoflavin methyl ether: New antibiotics from marine-derived streptomycetes. J. Antibiot. 2005, 58, 530-534. [CrossRef] [PubMed]

61. Manam, R.R.; Teisan, S.; White, D.J.; Nicholson, B.; Grodberg, J.; Neuteboom, S.T.C.; Lam, K.S.; Mosca, D.A.; Lloyd, G.K.; Potts, B.C.M. Lajollamycin, a nitro-tetraene spiro- $\beta$-lactone- $\gamma$-lactam antibiotic from the marine actinomycete Streptomyces nodosus. J. Nat. Prod. 2005, 68, 240-243. [CrossRef] [PubMed]

62. Maskey, R.P.; Li, F.C.; Qin, S.; Fiebig, H.H.; Laatsch, H. Chandrananimycins A-C: Production of novel anticancer antibiotics from a marine Actinomadura sp. isolate M048 by variation of medium composition and growth conditions. J. Antibiot. 2003, 56, 622-629. [CrossRef]

63. Fariq, A.; Yasmin, A.; Jamil, M. Production, characterization and antimicrobial activities of bio-pigments by Aquisalibacillus elongatus MB592, Salinicoccus sesuvii MB597, and Halomonas aquamarina MB598 isolated from Khewra Salt Range, Pakistan. Extremophiles 2019, 23, 435-449. [CrossRef]

64. Trenozhnikova, L.; Azizan, A. Discovery of actinomycetes from extreme environments with potential to produce novel antibiotics. Cent. Asian J. Glob. Health 2018, 7, 337. [CrossRef]

65. Kumar, R.R.; Jadeja, V.J. Characterization and partial purification of an antibacterial agent from halophilic actinomycete Kocuria sp. strain rsk4. BioImpacts 2018, 8, 253-261. [CrossRef]

66. Ballav, S.; Kerkar, S.; Thomas, S.; Augustine, N. Halophilic and halotolerant actinomycetes from a marine saltern of Goa, India producing anti-bacterial metabolites. J. Biosci. Bioeng. 2015, 119, 323-330. [CrossRef]

67. Ray, L.; Suar, M.; Pattnaik, A.K.; Raina, V. Streptomyces chilikensis sp. nov., a halophilic streptomycete isolated from brackish water sediment. Int. J. Syst. Evol. Microbiol. 2013, 63, 2757-2764. [CrossRef]

68. Rao, K.V.R. Isolation and characterization of antagonistic actinobacteria from mangrove soil. J. Biochem. Tech. 2012, 3, 361-365.

69. Mangamuri, U.K.; Vijayalakshmi Muvva, V.; Poda, S.; Kamma, S. Isolation, identification and molecular characterization of rare actinomycetes from mangrove ecosystem of Nizampatnam. Malays. J. Microbiol. 2012, 8, 83-91. [CrossRef]

70. Kamat, T.; Kerkar, S. Bacteria from salt pans: A potential resource of antibacterial metabolites. RRST-Biotech. 2011, 3, 46-52.

71. Gayathri, A.; Madhanraj, P.; Panneerselvam, A. Diversity, antibacterial activity and molecular characterization of actinomycetes isolated from salt pan region of Kodiakarai, Nagapattinam DT. Asian J. Pharm. Technol. 2011, 1, 79-81.

72. Meklat, A.; Sabaou, N.; Zitouni, A.; Mathieu, F.; Lebrihi, A. Isolation, taxonomy, and antagonistic properties of halophilic actinomycetes in Saharan soils of Algeria. Appl. Environ. Microbiol. 2011, 77, 6710-6714. [CrossRef] [PubMed]

73. Jose, A.; Santhi, S.; Solomon, R.D.J. In vitro antimicrobial potential and growth characteristics of Nocardiopsis sp. JAJ16 isolated from crystallizer pond. Int. J. Curr. Res. 2010, 3, 024-026.

74. Saurav, K. Diversity and optimization of process parameters for the growth of Streptomyces VITSVK9 spp. isolated from Bay of Bengal, India. J. Nat. Environ. Sci. 2010, 1, 56-65.

75. Suthindhir, K.; Kannabiran, K. Cytotoxic and antimicrobial potential of actinomycete species Saccharopolyspora salina VITSDK4 isolated from the Bay of Bengal coast of India. Am. J. Infect. Dis. 2009, 5, 90-98. [CrossRef]

76. Suthindhiran, K.; Kannabiran, K. Hemolytic activity of Streptomyces VITSDK1 spp. isolated from marine sediments in Southern India. J. Mycol. Médicale 2009, 19, 77-86. [CrossRef]

77. Cao, L.; Yun, W.; Tang, S.; Zhang, P.; Mao, P.; Jing, X.; Wang, C.; Lou, K. Biodiversity and enzyme screening of actinomycetes from Hami lake. Wei Sheng Wu Xue Bao 2009, 49, 287-293. 
78. Ramesh, S.; Mathivanan, N. Screening of marine actinomycetes isolated from the Bay of Bengal, India for antimicrobial activity and industrial enzymes. World J. Microbiol. Biotechnol. 2009, 25, 2103-2111. [CrossRef]

79. Hakvåg, S.; Fjærvik, E.; Josefsen, K.; Ian, E.; Ellingsen, T.; Zotchev, S. Characterization of Streptomyces spp. isolated from the sea surface microlayer in the Trondheim Fjord, Norway. Mar. Drugs 2008, 6, 620-635. [CrossRef]

80. Dhanasekaran, D.; Rajakumar, G.; Sivamani, P.; Selvamani, S.; Panneerselvam, A.; Thajuddin, N. Screening of salt pans actinomycetes for antibacterial agents. Internet J. Microbiol. 2004, 1, 1-4.

81. Magarvey, N.A.; Keller, J.M.; Bernan, V.; Dworkin, M.; Sherman, D.H. Isolation and characterization of novel marine-derived actinomycete taxa rich in bioactive metabolites. Appl. Environ. Microbiol. 2004, 70, 7520-7529. [CrossRef]

82. Kokare, C.R.; Mahadik, K.R.; Kadam, S.S.; Chopade, B.A. Isolation, characterization and antimicrobial activity of marine halophilic Actinopolyspora species AH1 from the west coast of India. Curr. Sci. 2004, 86, 5.

83. Meseguer, I.; Rodríguez-Valera, F.; Ventosa, A. Antagonistic interactions among halobacteria due to halocin production. FEMS Microbiol. Lett. 1986, 36, 177-182. [CrossRef]

84. Torreblanca, M.; Meseguer, I.; Ventosa, A. Production of halocins is a practically universal feature of archaeal halophilic rods. Lett. Appl. Microbiol. 1994, 19, 201-205. [CrossRef]

85. Shand, R.F.; Leyva, K.J. Peptide and protein antibiotics from the domain Archaea: Halocins and sulfolobicins. In Bacteriocins: Ecology and Evolution; Riley, M.A., Chavan, M.A., Eds.; Springer: Berlin/Heidelberg, Germany, 2007; pp. 93-109.

86. Atanasova, N.S.; Pietilä, M.K.; Oksanen, H.M. Diverse antimicrobial interactions of halophilic archaea and bacteria extend over geographical distances and cross the domain barrier. MicrobiologyOpen 2013, 2, 811-825. [CrossRef]

87. Corral, P.; Esposito, F.P.; Tedesco, P.; Falco, A.; Tortorella, E.; Tartaglione, L.; Festa, C.; D’Auria, M.V.; Gnavi, G.; Varese, G.C.; et al. Identification of a Sorbicillinoid-producing Aspergillus strain with antimicrobial activity against Staphylococcus aureus: A new polyextremophilic marine fungus from Barents Sea. Mar. Biotechnol. 2018, 20, 502-511. [CrossRef]

88. Besse, A. Antimicrobial peptides and proteins in the face of extremes: Lessons from archaeocins. Biochimie 2015, 118, 344-355. [CrossRef]

89. Quadri, I.; Hassani, I.I.; l'Haridon, S.; Chalopin, M.; Hacène, H.; Jebbar, M. Characterization and antimicrobial potential of extremely halophilic archaea isolated from hypersaline environments of the Algerian Sahara. Microbiol. Res. 2016, 186-187, 119-131. [CrossRef]

90. Pi, B.; Yu, D.; Dai, F.; Song, X.; Zhu, C.; Li, H.; Yu, Y. A Genomics based discovery of secondary metabolite biosynthetic gene clusters in Aspergillus ustus. PLoS ONE 2015, 10, e0116089. [CrossRef]

91. Kjærbølling, I.; Vesth, T.C.; Frisvad, J.C.; Nybo, J.L.; Theobald, S.; Kuo, A.; Bowyer, P.; Matsuda, Y.; Mondo, S.; Lyhne, E.K.; et al. Linking secondary metabolites to gene clusters through genome sequencing of six diverse Aspergillus species. Proc. Natl. Acad. Sci. USA 2018, 115, E753-E761. [CrossRef]

92. Wolfender, J.-L.; Litaudon, M.; Touboul, D.; Queiroz, E.F. Innovative omics-based approaches for prioritisation and targeted isolation of natural products-New strategies for drug discovery. Nat. Prod. Rep. 2019, 36, 855-868. [CrossRef]

93. Metcalf, J.A.; Funkhouser-Jones, L.J.; Brileya, K.; Reysenbach, A.-L.; Bordenstein, S.R. Antibacterial gene transfer across the tree of life. eLife 2014, 25, 3. [CrossRef] [PubMed]

94. Plemenitaš, A.; Lenassi, M.; Konte, T.; Kejžar, A.; Zajc, J.; Gostinčar, C.; Gunde-Cimerman, N. Adaptation to high salt concentrations in halotolerant/halophilic fungi: A molecular perspective. Front. Microbiol. 2014, 5, 199. [CrossRef] [PubMed]

95. Gunde-Cimerman, N.; Plemenitaš, A.; Oren, A. Strategies of adaptation of microorganisms of the three domains of life to high salt concentrations. FEMS Microbiol. Rev. 2018, 42, 353-375. [CrossRef] [PubMed]

96. Plemenitaš, A.; Vaupotič, T.; Lenassi, M.; Kogej, T.; Gunde-Cimerman, N. Adaptation of extremely halotolerant black yeast Hortaea werneckii to increased osmolarity: A molecular perspective at a glance. Stud. Mycol. 2008, 61, 67-75. [CrossRef]

97. Moubasher, A.-A.H.; Abdel-Sater, M.A.; Soliman, Z.S.M. Yeasts and filamentous fungi associated with some dairy products in Egypt. J. Mycol. Médicale 2018, 28, 76-86. [CrossRef] 
98. Chamekh, R.; Deniel, F.; Donot, C.; Jany, J.-L.; Nodet, P.; Belabid, L. Isolation, identification and enzymatic activity of halotolerant and halophilic fungi from the Great Sebkha of Oran in Northwestern of Algeria. Mycobiology 2019, 47, 230-241. [CrossRef]

99. Chung, D.; Kim, H.; Choi, H.S. Fungi in salterns. J. Microbiol. 2019, 57, 717-724. [CrossRef]

100. Zheng, J.; Wang, Y.; Wang, J.; Liu, P.; Li, J.; Zhu, W. Antimicrobial ergosteroids and pyrrole derivatives from halotolerant Aspergillus flocculosus PT05-1 cultured in a hypersaline medium. Extremophiles 2013, 17, 963-971. [CrossRef]

101. Wang, Y.; Zheng, J.; Liu, P.; Wang, W.; Zhu, W. Three new compounds from Aspergillus terreus PT06-2 grown in a high salt medium. Mar. Drugs 2011, 9, 1368-1378. [CrossRef]

102. Ali, I.; Siwarungson, N.; Punnapayak, H.; Lotrakul, P.; Prasongsuk, S.; Bankeeree, W.; Rakshit, S.K. Screening of potential biotechnological applications from obligate halophilic fungi, isolated from a man-made solar saltern located in Phetchaburi province, Thailand. Pak. J. Bot. 2014, 46, 983-988.

103. Lebogang, L.; Taylor, J.E.; Mubyana-John, T. A preliminary study of the fungi associated with saltpans in Botswana and their anti-microbial properties. Bioremediation Biodivers. Bioavailab. 2009, 3, 61-71.

104. Safarpour, A.; Amoozegar, M.A.; Ventosa, A. Hypersaline environments of Iran: Prokaryotic biodiversity and their potentials in microbial biotechnology. In Extremophiles in Eurasian Ecosystems: Ecology, Diversity, and Applications; Egamberdieva, D., Birkeland, N.-K., Panosyan, H., Li, W.-J., Eds.; Springer: Singapore, 2018; Volume 8, pp. 265-298.

105. Safarpour, A.; Ebrahimi, M.; Shahzadeh Fazeli, S.A.; Amoozegar, M.A. Supernatant metabolites from halophilic archaea to reduce tumorigenesis in prostate cancer in-vitro and in-vivo. Iran. J. Pharm. Res. 2019, 18, 241-253. [PubMed]

106. Chen, L.; Wang, G.; Bu, T.; Zhang, Y.; Wang, Y.; Liu, M.; Lin, X. Phylogenetic analysis and screening of antimicrobial and cytotoxic activities of moderately halophilic bacteria isolated from the Weihai Solar Saltern (China). World J. Microbiol. Biotechnol. 2010, 26, 879-888. [CrossRef]

107. Zhao, L.-X.; Huang, S.-X.; Tang, S.-K.; Jiang, C.-L.; Duan, Y.; Beutler, J.A.; Henrich, C.J.; McMahon, J.B.; Schmid, T.; Blees, J.S.; et al. Actinopolysporins A-C and tubercidin as a Pdcd4 stabilizer from the halophilic actinomycete Actinopolyspora erythraea YIM 90600. J. Nat. Prod. 2011, 74, 1990-1995. [CrossRef] [PubMed]

108. Sagar, S.; Esau, L.; Hikmawan, T.; Antunes, A.; Holtermann, K.; Stingl, U.; Bajic, V.B.; Kaur, M. Cytotoxic and apoptotic evaluations of marine bacteria isolated from brine-seawater interface of the Red Sea. BMC Complement. Altern. Med. 2013, 13, 29. [CrossRef] [PubMed]

109. Sagar, S.; Esau, L.; Holtermann, K.; Hikmawan, T.; Zhang, G.; Stingl, U.; Bajic, V.B.; Kaur, M. Induction of apoptosis in cancer cell lines by the Red Sea brine pool bacterial extracts. BMC Complement. Altern. Med. 2013, 13, 344. [CrossRef]

110. Liu, H.; Xiao, L.; Wei, J.; Schmitz, J.C.; Liu, M.; Wang, C.; Cheng, L.; Wu, N.; Chen, L.; Zhang, Y.; et al. Identification of Streptomyces sp. nov. WH26 producing cytotoxic compounds isolated from marine solar saltern in China. World J. Microbiol. Biotechnol. 2013, 29, 1271-1278. [CrossRef]

111. Kim, S.-H.; Shin, Y.; Lee, S.-H.; Oh, K.-B.; Lee, S.K.; Shin, J.; Oh, D.-C. Salternamides A-D from a halophilic Streptomyces sp. actinobacterium. J. Nat. Prod. 2015, 78, 836-843. [CrossRef]

112. Bach, D.-H.; Kim, S.-H.; Hong, J.-Y.; Park, H.J.; Oh, D.-C.; Lee, S.K. Salternamide A suppresses hypoxia-induced accumulation of HIF-1 $\alpha$ and induces apoptosis in human colorectal cancer cells. Mar. Drugs 2015, 13, 6962-6976. [CrossRef]

113. Sarvari, S.; Seyedjafari, E.; Amoozgar, M.A.; Bakhshandeh, B. The effect of moderately halophilic bacteria supernatant on proliferation and apoptosis of cancer cells and mesenchymal stem cells. Cell. Mol. Biol. Noisy Gd. Fr. 2015, 61, 30-34.

114. Sun, M.; Zhang, X.; Hao, H.; Li, W.; Lu, C. Nocarbenzoxazoles A-G, benzoxazoles produced by halophilic Nocardiopsis lucentensis DSM 44048. J. Nat. Prod. 2015, 78, 2123-2127. [CrossRef] [PubMed]

115. Son, S.; Ko, S.-K.; Jang, M.; Kim, J.; Kim, G.; Lee, J.; Jeon, E.; Futamura, Y.; Ryoo, I.-J.; Lee, J.-S.; et al. New cyclic lipopeptides of the iturin class produced by saltern-derived Bacillus sp. KCB14S006. Mar. Drugs 2016, 14, 72. [CrossRef] [PubMed]

116. Prathiba, S.; Jayaraman, G. Evaluation of the anti-oxidant property and cytotoxic potential of the metabolites extracted from the bacterial isolates from mangrove forest and saltern regions of South India. Prep. Biochem. Biotechnol. 2018, 48, 750-758. [CrossRef] [PubMed] 
117. Lawrance, A.; Balakrishnan, M.; Gunasekaran, R.; Srinivasan, R.; Valsalan, V.N.; Gopal, D.; Ramalingam, K. Unexplored deep sea habitats in active volcanic Barren Island, Andaman and Nicobar Islands are sources of novel halophilic eubacteria. Infect. Genet. Evol. 2018, 65, 1-5. [CrossRef]

118. Neelam, D.K.; Agrawal, A.; Tomer, A.K.; Bandyopadhayaya, S.; Sharma, A.; Jagannadham, M.V.; Mandal, C.C.; Dadheech, P.K. A Piscibacillus sp. isolated from a soda lake exhibits anticancer activity against breast cancer MDA-MB-231 cells. Microorganisms 2019, 7, 34. [CrossRef]

119. Donio, M.B.S.; Ronica, F.A.; Viji, V.T.; Velmurugan, S.; Jenifer, J.S.C.A.; Michaelbabu, M.; Dhar, P.; Citarasu, T. Halomonas sp. BS4, a biosurfactant producing halophilic bacterium isolated from solar salt works in India and their biomedical importance. SpringerPlus 2013, 2, 149. [CrossRef]

120. Ruiz-Ruiz, C.; Srivastava, G.K.; Carranza, D.; Mata, J.A.; Llamas, I.; Santamaría, M.; Quesada, E.; Molina, I.J. An exopolysaccharide produced by the novel halophilic bacterium Halomonas stenophila strain B100 selectively induces apoptosis in human T leukaemia cells. Appl. Microbiol. Biotechnol. 2011, 89, 345-355. [CrossRef]

121. Sarilmiser, H.K.; Ozlem, A.; Gonca, O.; Arga, K.Y.; Toksoy Oner, E. Effective stimulating factors for microbial levan production by Halomonas smyrnensis AAD6T. J. Biosci. Bioeng. 2015, 119, 455-463. [CrossRef]

122. Rezaeeyan, Z.; Safarpour, A.; Amoozegar, M.A.; Babavalian, H.; Tebyanian, H.; Shakeri, F. High carotenoid production by a halotolerant bacterium, Kocuria sp. strain QWT-12 and anticancer activity of its carotenoid. EXCLI J. 2017, 16, 840-851.

123. Zolfaghar, M.; Amoozegar, M.A.; Khajeh, K.; Babavalian, H.; Tebyanian, H. Isolation and screening of extracellular anticancer enzymes from halophilic and halotolerant bacteria from different saline environments in Iran. Mol. Biol. Rep. 2019, 46, 3275-3286. [CrossRef]

124. Ghasemi, A.; Asad, S.; Kabiri, M.; Dabirmanesh, B. Cloning and characterization of Halomonas elongata L-asparaginase, a promising chemotherapeutic agent. Appl. Microbiol. Biotechnol. 2017, 101, 7227-7238. [CrossRef] [PubMed]

125. Hamidi, M.; Mirzaei, R.; Delattre, C.; Khanaki, K.; Pierre, G.; Gardarin, C.; Petit, E.; Karimitabar, F.; Faezi, S. Characterization of a new exopolysaccharide produced by Halorubrum sp. TBZ112 and evaluation of its anti-proliferative effect on gastric cancer cells. 3 Biotech 2019, 9, 1. [CrossRef] [PubMed]

126. Abbes, M.; Baati, H.; Guermazi, S.; Messina, C.; Santulli, A.; Gharsallah, N.; Ammar, E. Biological properties of carotenoids extracted from Halobacterium halobium isolated from a Tunisian solar saltern. BMC Complement. Altern. Med. 2013, 13, 255. [CrossRef] [PubMed]

127. Hou, J.; Cui, H.-L. In vitro antioxidant, antihemolytic, and anticancer activity of the carotenoids from halophilic archaea. Curr. Microbiol. 2018, 75, 266-271. [CrossRef]

128. Xiao, L.; Liu, H.; Wu, N.; Liu, M.; Wei, J.; Zhang, Y.; Lin, X. Characterization of the high cytochalasin E and rosellichalasin producing Aspergillus sp. nov. F1 isolated from marine solar saltern in China. World J. Microbiol. Biotechnol. 2013, 29, 11-17. [CrossRef]

129. León, M.J.; Fernández, A.B.; Ghai, R.; Sánchez-Porro, C.; Rodriguez-Valera, F.; Ventosa, A. From metagenomics to pure culture: Isolation and characterization of the moderately halophilic bacterium Spiribacter salinus gen. nov., sp. nov. Appl. Environ. Microbiol. 2014, 80, 3850-3857. [CrossRef]

130. Hamm, J.N.; Erdmann, S.; Eloe-Fadrosh, E.A.; Angeloni, A.; Zhong, L.; Brownlee, C.; Williams, T.J.; Barton, K.; Carswell, S.; Smith, M.A.; et al. Unexpected host dependency of Antarctic nanohaloarchaeota. Proc. Natl. Acad. Sci. USA 2019, 116, 14661-14670. [CrossRef]

131. Blin, K.; Kim, H.U.; Medema, M.H.; Weber, T. Recent development of antiSMASH and other computational approaches to mine secondary metabolite biosynthetic gene clusters. Brief. Bioinform. 2019, 20, 1103-1113. [CrossRef]

132. Wang, S.; Zheng, Z.; Zou, H.; Li, N.; Wu, M. Characterization of the secondary metabolite biosynthetic gene clusters in archaea. Comput. Biol. Chem. 2019, 78, 165-169. [CrossRef]

133. Zheng, Y.; Saitou, A.; Wang, C.-M.; Toyoda, A.; Minakuchi, Y.; Sekiguchi, Y.; Ueda, K.; Takano, H.; Sakai, Y.; Abe, K.; et al. Genome features and secondary metabolites biosynthetic potential of the class Ktedonobacteria. Front. Microbiol. 2019, 10, 893. [CrossRef] 
134. Weber, T.; Blin, K.; Duddela, S.; Krug, D.; Kim, H.U.; Bruccoleri, R.; Lee, S.Y.; Fischbach, M.A.; Müller, R.; Wohlleben, W.; et al. antiSMASH 3.0-A comprehensive resource for the genome mining of biosynthetic gene clusters. Nucleic Acids Res. 2015, 43, W237-W243. [CrossRef] [PubMed]

135. Mohimani, H.; Gurevich, A.; Shlemov, A.; Mikheenko, A.; Korobeynikov, A.; Cao, L.; Shcherbin, E.; Nothias, L.-F.; Dorrestein, P.C.; Pevzner, P.A. Dereplication of microbial metabolites through database search of mass spectra. Nat. Commun. 2018, 9, 4035. [CrossRef] [PubMed] 